\title{
CONTROLE DA MORFOGÊNESE in vitro DE TRÊS ESPÉCIES DE BROMÉLIAS ENDÊMICAS DO SUDESTE BRASILEIRO
}

\section{LEONARDO ALVES CARNEIRO}

Biólogo

Orientador: Prof. Dr. OTTO JESU CROCOMO

Tese apresentada à Escola Superior de Agricultura "Luiz de Queiroz", Universidade de São Paulo, para obtenção do título de Doutor em Agronomia, Área de Concentração: Solos e Nutrição de Plantas.

PIRACICABA

Estado de São Paulo - Brasil

Novembro - 1997 
Dados Internacionais de Catalogação na Publicação (CIP) DIVISĀo DE BIBLIOTECA E DOCUMENTAÇĀO - Campus "Luiz de Queiroz"/USP

Carneiro, Leonardo Alves

Controle da morfogênese in vitro de três espécies de bromélias endêmicas do sudeste brasileiro / Leonardo Alves Carneiro. - - Piracicaba, 1997.

87 p. : il.

Tese (doutorado) - Escola Superior de Agricultura Luiz de Queiroz, 1997. Bibliografia.

1. Bromeliácea 2. Morfogênese 3. Propagaçāo in vitro I. Título

CDD 584.22 


\title{
CONTROLE DA MORFOGÊNESE in vitro DE TRÊS ESPÉCIES DE BROMÉLIAS ENDÊMICAS DO SUDESTE BRASILEIRO
}

\author{
LEONARDO ALVES CARNEIRO
}

Aprovada em: 16.12.1997

Comissão julgadora:

Profa. Dra. Helaine Carrer

ESALQ/USP

Profa. Dra. Maria Lúcia Carneiro Vieira

ESALQ/USP

Prof. Dr. Otto Jesu Crocomo

ESALQ/USP

Prof. Dr. Fernando Broetto

UNESP/BOTUCATU

Prof. Dr. Antônio Fernando Caetano Tombolato

IAC

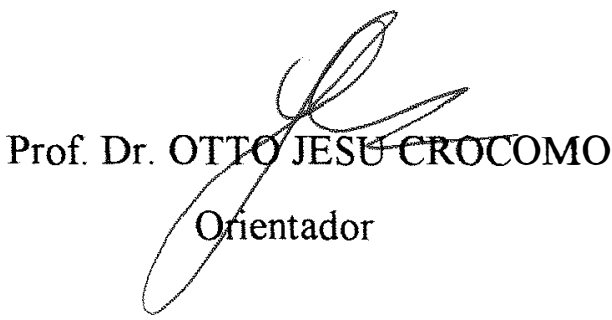




\section{A DEUS}

pela oportunidade da vida

\section{À ANA MARIA}

pelo amor e pela família.

\section{A JOSÉ}

que acompanhou de outra dimensão esta tarefa, pelo êxito de sua função paterna, sempre exercida através de exemplos de dignidade e solidariedade

DEDICO

\section{À LETíCIA, TALITA e PRISCILA}

"quando brotarem as flores quando crescerem as matas quando colherem os frutos digam o gosto pra mim."

pela felicidade do reencontro no lar, nesta vida. as minhas filhas

OFEREÇO 


\section{AGRADECIMENTOS}

Ao professor Dr. Otto Jesu Crocomo do Centro de Biotecnologia Agrícola (CEBTEC) ESALQ/USP, pela orientação,estimulo,amizade e transmissão de sua experiência universitária e científica .O seu exemplo de obstinação na criação do CEBTEC me incentivou para a constituição do LABMIT(UERJ) onde se realizou parte deste trabalho.

À professora Dra. Elisabeth Atalla Mansur que não poupou dedicação e estímulo como co-orientadora desse estudo além de assumir com raro entusiasmo e profissionalismo a coordenação do LABMIT.

À amiga Rachel, bióloga do LABMIT que mesclou assistência e dedicação no labor diário. Sua serenidade, um tanto maternal, contribuiu bastante para atingir os objetivos desse trabalho.

As biólogas, Maria Helena e Ana Paula, pela participação competente nos experimentos de micropropagação e preparo de lâminas, além da satisfação das suas amizades.

Ao biólogo Gustavo, pela ajuda valiosa nos experimentos de micropropagação e aclimatização, além da alegria que sempre demonstrou.

À bióloga Renata que excedeu-se em eficiência na digitação e ordenação dos originais dessa tese, sempre com muita simpatia.

À amiga Telma, por sua atenção e convivência diária sempre muito positivas.

Ao amigo Luiz Felipe do Setor de Ensino - DBAV/UERJ - que foi o técnico sempre atento ao pleno funcionamento do LABMIT.

À Ana Clara e Rosangela, pela força nos instantes derradeiros deste trabalho.

À Coordenação de Aperfeiçoamento de Pessoal de Nivel Superior (CAPES) pelo auxílio financeiro para a realização do curso.

À Escola Superior de Agricultura "Luiz de Queiroz" (ESALQ/USP) em especial à Coordenação do Curso de Pós-Graduação em Solos e Nutrição de Plantas, professores Geraldo França e Francisco Monteiro pela oportunidade da realização do Curso.

À Andréa Costa e Marcelo Senna, pela amizade, ajuda nas coletas e identificação das espécies.

À professora Ana Donato DBAV/UERJ, pela ajuda e disponibilidade dos recursos necessários para o estudo histológico. 
Ao professor Carlos Tadeu - Depto. de Estatística/ESALQ, pelo auxílio nas análises estatísticas.

Ao Dr. Elton Leme, pela colaboração na obtenção de material bibliográfico.

À bióloga Dorothy Sue Dunn, pela revisão da versão em inglês de uma das publicações originadas deste trabalho.

Aos amigos do DBCG/UERJ - Gilberto, Fátima, Vítor, Marcos, Érika, Cláudia, Marcelo, Mauro, Simone, Madalena, Otacílio, Marli, Lia e Vânia pelo incentivo e companhia em muitos momentos.

Aos colegas do DBCG que me substituíram durante o afastamento.

Aos amigos da ESALQ/Piracicaba, Maria Solizete, Gallo, Murilo, Ênio, Romeu, Amaral, Fátima, João, Fernando, Helaine e Diva, pelas diversas provas de amizade que não cessam de proporcionar.

Aos professores Mauro Velho e Patrícia, pelo companheirismo e auxílio no preparo das transparências.

Aos professores Simon, Sirlene, Nilcéa e Hésio Cordeiro e aos funcionários do CEPUERJ, pelo apoio na criação do LABMIT/UERJ.

Aos colegas da UERJ ligados a Sub-reitoria de Pós-graduação e Pesquisa, Roberto Ávila, José Reinaldo, Maria Del Carmen, Rosinha e Ágda, pelo acompanhamento e apoio institucional.

As professoras, Lúcia, Maria da Graça, Alvanice, Norma, Maria Conceição e à funcionária Tânia, por todo apoio demonstrado ao longo do curso.

À minha mãe Emília, pelo estímulo e preocupação carinhosa.

Ao amigo Luiz Antônio pela inúmeras demonstrações de amizade.

Aos colegas de curso, José Simplício, Ricardo e Cássio, pelos momentos de estudo.

Aos professores da ESALQ, Natal e Gutierrez, pelo incentivo e exemplo de docentes-pesquisadores.

Ao professor Roberto Rossielo da UFRRJ, pelas lições de solos e de vida.

\section{Amar é o grande desafio.}

Joanna de Ângelis 


\section{SUMÁRIO}

Página

LISTA DE TABELAS...................................................

LISTA DE QUADROS .................................................. $\mathrm{x}$

LISTA DE FIGURAS ............................................... xi

LISTA DE ABREVIATURAS........................................... xii

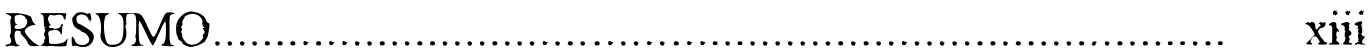

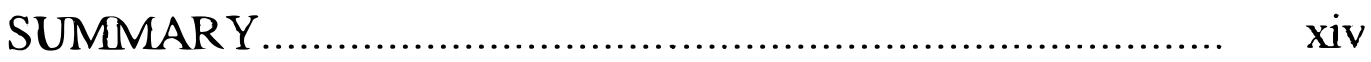

1 INTRODUÇÃO ..................................................... 1

2 REVISÃO DA LITERATURA .........................................

2.1 Características Gerais das Bromélias....................... 3

2.2 Importância Ecológica.......................................... 5

2.3 Importância Econômica.......................................... 5

2.4 Preservação....................................................... 7

2.5 Cultura de Tecidos de Bromélias.............................. 9 
3 REGENERAÇÃO IN ITTRO A PARTIR DE EXPLANTES DE FOLHAS DE Neoregelia cruenta (R. GRAHAM) L. SMITH, UMA BROMÉLIA ENDÊMICA DO SUDESTE BRASILEIRO.

3.1 Introdução

3.2 Material e Métodos.

3.2.1 Meio de Cultura e condições....................... 16

3.2.2 Cultura de explantes................................ 16

3.3 Resultados e Discussão...................................... 18

3.3.1 Germinação de sementes.......................... 18

3.3.2 Regeneração de brotos a partir de gemas axilares

3.3.3 Regeneração de explantes de folhas

4 PROPAGACÃO CLONAL DE Cryptanthus sinuosus L. B. SMITH, UMA BROMÉLIA ESTOLONIFERA E ENDÊMICA DO RIO DE JANEIRO, BRASIL

4.1 Introdução

4.2 Material e Métodos

4.2.1 Condicões de Cultura.

28

4.2.2 Cultura do Explante

4.3 Resultados

4.4 Discussão.

5 EFEITO DE DIFERENTES CONCENTRAÇÕES DE ANA E BAP NA REGENERAÇÃO DE Cryptanthus sinuosus L. B. SMITH.

5.1 Introdução

5.2 Material e Métodos

5.2.1 Procedimentos Histológicos.

5.3 Resultados e Discussão.

5.3.1 Estruturas Histológicas da Protuberâncias. . 
6 REGENERAÇÃO IN VITRO A PARTIR DE EXPLANTES DE FOLHAS DE Quesnelia arvensis (VELLOZO) MEZ

6.1 Introdução.................................................... 47

6.2 Material e Métodos.......................................... 48

6.2.1 Meios e condições de cultura..................... 48

6.2.2 Cultura de Explantes................................ 48

6.3 Resultados e Discussão....................................... $\quad 50$

7 ACLIMATIZAÇÃO DE PLÂNTULAS DE Cryptanthus sinuosus, Neoregelia cruenta e Quesnelia arvensis ......... $\quad 56$

7.1 Introdução.................................................... 56

7.2 Material e Métodos........................................... 61

7.2.1 Material Botânico..................................... 61

7.2.2 Condição do Experimento......................... 62

7.2.3 Análise Histológica.................................. 63

7.3 Resultados e Discussão ...................................... 64

7.3.1 Avaliação da Massa de Matéria Fresca...... 64

7.3.2 Análise Histológica.................................. 65

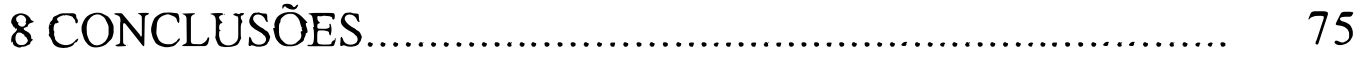

REFERÊNCIAS BIBLIOGRÁFICAS ……........................ 78 


\section{LISTA DE TABELAS}

Tabela $n^{\circ}$

Página

1. Efeito da idade do explante e diferentes combinações de BAP/ANA na frequência de regeneração e número de brotos e plantas completas por explante de folha de N.cruenta.

2. Efeito de diferentes combinações de BAP/ANA sobre a percentagem de regeneração e o número de brotos $\mathrm{e}$ plântulas por explante de folha de Cryptanthus sinuosus

3. Número médio de brotos produzidos por explantes folia res, em resposta a diferentes concentrações de ANA e BAP 60 dias após o início da cultura.

4. Número médio de brotos de $Q$. arvensis originadas a partir de explantes caule+raiz,após 60 dias

5. Variação da massa de matéria fresca (MMF) em plantulas após 120 dias de aclimatização

\section{LISTA DE QUADROS}

\section{Quadro n}

1. Cultura de tecido de algumas bromélias.

2. Composição da solução nutritiva de Hoagland e Arnon citado por Gallo (1980) 


\section{LISTA DE FIGURAS}

Figura $\mathbf{n}^{\circ}$

Página

1. Regeneração in vitro de N.cruenta................................. 23

2. Regeneração in vitro de C. sinuosus............................. 33

3. Regeneração in vitro de C. sinuosus a partir de explantes foliares e caulinares,induzida por concentrações de BAP e ANA ..................................

4. Protuberâncias de explantes foliares de C.sinuosus após 2 meses de cultura em BAP $4,4 \mu \mathrm{M}$ e ANA $0,1 \mu \mathrm{M} \ldots \ldots$.

5. Regeneração in vitro de Q.arvensis.

6. Variação da massa de matéria fresca de agregados de ..gemas

7. Secção transversal de lâmina foliar de C.sinuosus mantida in vitro por 120 dias

8. Seç̧ão transversal de lâmina foliar de plântula de C.sinuosus mantida ex vitro por 120 dias.

9. Epiderme abaxial de lâmina foliar de plântula $C$. sinuosus mantidas por 120 dias (in vitro e ex vitro)

10. Mudas de $N$. cruenta, C.sinuosus e Q. arvensis após 120 dias na condição ex vitro.

11. Plantas de $C$, sinuosus e N.cruenta em substrato Plantmax após 120 dias na condição ex vitro......

12. Plantas de Q. arvensis em substrato Plantmax após 120 dias na condição ex vitro 


\section{CONTROLE DA MORFOGÊNESE IN VITRO DE TRÊS ESPÉCIES DE BROMÉLIAS ENDÊMICAS DO SUDESTE BRASILEIRO}

Autor: Leonardo Alves Carneiro Orientador: Prof. Dr. Otto Jesu Crocomo

\section{RESUMO}

Sistemas eficientes foram desenvolvidos para a indução de organogênese direta in vitro, a partir de explantes de plântulas de bromélias endêmicas do sudeste brasileiro.

Explantes foliares de Neoregelia cruenta(R.Graham)L.B.Smith foram induzidos em meio sólido suplementado por combinações de BAP e ANA, resultando na produção máxima de 450 plantas por semente.

Explantes foliares excisados de brotos oriundos de estolões de Cryptanthus sinuosus L.B. Smith e cultivados na presença de BAP, TDZ ou combinações de BAP e ANA resultaram na produção máxima de 400 plantas por broto original.

Um alto potencial multiplicativo foi obtido a partir de explantes de caule com raiz de Quesnelia arvensis(Vellozo)Mez., cultivados em meio MS líquido sem reguladores de crescimento, resultando na produção de 8300 plantas por semente, após cinco meses de cultura.

Avaliações histológicas e do ganho de massa de matéria fresca comprovaram a capacidade de adaptação rápida das plantas de C. sinuosus obtidas a condições ex vitro.

Os protocolos aqui desenvolvidos podem ser uma altemativa viável de produção para suprir o mercado e programas de reintrodução. Além disso, constituem base para o estabelecimento de metodologias de conservação in vitro. 


\title{
CONTROL OF MORPHOGENESIS IN VITRO OF THREE SPECIES OF ENDEMIC BROMELIADS FROM EASTERN BRAZIL
}

\author{
Author: Leonardo Alves Cameiro \\ Adviser: Prof.'Dr. Otto Jesu Crocomo
}

\section{SUMMARY}

Efficient systems for the induction of in vitro regeneration through direct organogenesis from explants of endemic bromeliads from Eastern Brazil were established.

Leaf explants of Neoregelia cruenta (R.Graham) were induced in solid medium supplemented with ANA/BAP combinations, resulting in a maximum production of 450 plants per seed.

Leaf explants excised from shoots derived from Cryptanthus sinuosus L.B. Smith stolons and cultivated in the presence of BAP, TDZ or BAP/ANA combinations resulted in maximum production of 400 plants per donor shoot.High multiplication potential was obtained from stem+root explants from Quesnelia arvensis(Vellozo)Mez. cultured in liquid MS medium free of growth regulators, resulting in the production of 8300 plants per seed, within five months of culture.

Evaluations of histological aspects and mass increase confinned the rapid adaptation potential of $C$. sinuosus plants to ex vitro conditions.

The protocols developed in this work can be a viable alternative for plant production in order to supply the market and reintroduction programs. Moreover, they are the first step for the establishment of in vitro conservation methodologies. 


\section{INTRODUÇÃO}

A família Bromeliaceae nas duas últimas décadas tem recebido atenção de um número crescente de pesquisadores e colecionadores, dedicados ao seu estudo. Há também uma popularização, que é coincidente com aumento da preocupação da humanidade com a conservação do patrimônio natural do planeta.

Estas plantas têm algumas peculiaridades que as destacam, como beleza de flores ou folhas, disposição de folhas, ocorrência em diversos habitat e importância ecológica, como abrigo e fonte de água e alimentos para comunidades animais. Algumas bromélias têm valor comercial no mercado interno e de exportação.

$\mathrm{O}$ interesse que se verifica recentemente, no Brasil, já ocorredesde o século passado, na Europa e Estados Unidos da América do Norte, o que explica a ocorrência de muitas espécies endêmicas brasileiras que originaram um grande número de híbridos.

Esta família, cuja distribuição está praticamente limitada às Américas, possui 50 gêneros e 2900 espécies. No Estado do Rio de Janeiro podem ser encontrados 20 desses gêneros e 245 espécies, segundo levantamentos recentes(Fontoura et al. , 1991). 
Várias espécies estão sob o risco de extinção por diferentes motivos entre os quais a destruição à rítmo acelerado de seus habitats, pela especulação imobiliária, o avanço das fronteiras de terras agricultáveis e o extrativismo seletivo que supre o comércio de plantas ornamentais. Entre essas espécies listam-se aquelas pesquisadas neste trabalho: Neoregelia cruenta (R. Graham) L.B. Smith; Cryptanthus sinuosus L.B. Smith e Quesnelia arvensis (Vellozo) Mez, as quais são endêmicas da região sudeste do Brasil.

Paralelamente às demais ações conservacionistas, a conservação in vitro é uma alternativa que pode ser desenvolvida para espécies dessa família. A base da conservação in vitro são os protocolos de micropropagação que, além disso, podem ser utilizados para a produção de mudas de qualidade em larga escala, contribuindo para a redução do extrativismo.

O desenvolvimento desses protocolos para cada uma das espécies em estudo constituiu-se no objetivo do presente trabalho, cujas estratégias adotadas basearam-se na utilização de estolões ou sementes numa abordagem não destrutiva, com retiradas mínimas de exemplares de plantas do ambiente, com a preocupação da otimização do processo de micropropagação visando ä produção final de mudas.Deve-se enfatizar que quando o processo de regeneração in vitro apresenta um alta eficiência temse a possibilidade da comercialização das espécies, que contribui para a diminuição do extrativismo e a consequente popularização das mesmas. 


\section{REVISÃO DE LITERATURA}

\subsection{Características gerais das bromélias}

As bromélias possuem distribuição limitada às Américas. Somente uma espécie, Pitcairnia feliciana, ocorre no continente africano. A família Bromeliaceae é composta por 50 gêneros e 2900 espécies,divididas em 3 subfamílias. Dentre os ambientes em que as bromélias podem ser encontradas, incluem-se as restingas, os campos de altitude, os campos rupestres, a caatinga, desertos mexicanos, florestas como a Mata Atlântica e as cadeias montanhosas do noroeste da América do Sul e na América Central. O leste brasileiro é a região que possui a maior diversidade de espécies de bromélias no Brasil (Luther, 1994; Leme \& Marigo, 1993).

A família é representada, no Rio de Janeiro, por 20 gêneros e 245 espécies. A maior diversidade de bromélias, compreendendo $81,8 \%$ dos táxons específicos e intra-específicos, ocorrem na Floresta Tropical Costeira. As restingas possuem $23,8 \%$ destes táxons, dos quais 3,2\% são endêmicos (Fontoura et al., 1991).

As bromélias são classificadas como monocárpicas perenes. Durante o ciclo vital, que pode variar de alguns meses a muitos anos, de acordo com a espécie e/ou condições ambientais, o indivíduo floresce e frutifica somente 
uma vez. A propagação vegetativa é uma estratégia comum na família e sua ocorrência praticamente não apresenta exceção (Cândido, 1995, 1996).

As folhas das bromélias possuem distribuição alterna espiralada e os entrenós são muito curtos, dando à planta uma forma característica de roseta. O caule fica, em geral, totalmente envolvido pelas folhas, e a formação em roseta possibilita o acúmulo de água e detritos por esses vegetais, em uma estrutura denominada tanque ou cisterna. Os tricomas, indumento que recobre as folhas, desempenham importante papel na absorção de água e nutrientes. São formados por pêlos peltados, com um escudo central de células, circundado por um anel de células livres, vazias e com paredes espessadas. Um grande número de plasmodesmos são encontrados nas áreas de contato não cutinizadas, entre as células vivas da epiderme. Além do papel na absorção, os tricomas são importantes na reflexão da luz e na proteção da planta contra a transpiração excessiva, em espécies xerofiticas. (Costa, 1996)

As bromélias podem ser reunidas em três grandes grupos, com base na forma da roseta e no tipo de nutrição. O primeiro deles reúne as espécies que, apesar da presença dos tricomas foliares, também apresentam raízes funcionais. O segundo grupo é formado pelas espécies com folhas largas, que acumulam água e detritos em seus tanques. Nesse caso, a absorção de nutrientes ocorre primordialmente através dos tricomas foliares, enquanto que pequenas taxas de absorção são observadas nas raízes. O terceiro grupo é composto pelas espécies ditas atmosféricas, pertencentes ao gênero Tillandsia. As espécies desse grupo não apresentam tanque e absorvem água e nutrientes diretamente dos aerossóis atmosféricos através dos tricomas que, 
nestes casos, são muito desenvolvidos e numerosos. (Costa, 1996). São plantas que apresentam reações de assimilação do carbono do tipo CAM (metabolismo ácido das Crassuláceas). O ganho de $\mathrm{CO}_{2}$ da atmosfera ocorre à noite e este é conservado sob a forma de malato, sendo descarboxilado durante o dia, em presença de maior fluxo de energia na folha, sob a forma de NADP e ATP (Magalhães,1979).

\subsection{Importância ecológica}

As bromélias são consideradas essenciais para a garantia da diversidade nos locais onde ocorrem. Sua roseta tipo tanque em algumas espécies, forma um micro habitat para diversos grupos de organismos, o que lhes confere um importante papel ecológico (Oliveira et al., 1994; Van Sluys \& Stotz, 1995 e Pizo, 1994). Além disso, muitas são consideradas como espécies pioneiras, ao longo da sucessão ecológica (Leme, 1993; Hay \& Lacerda, 1980) outras são rupículas ou epífitas, podendo localizar-se desde a base até o topo das árvores (Leme \& Marigo, 1993).

\subsection{Importância econômica}

A importância econômica das bromélias tem crescido nos últimos anos, com sua utilização em projetos paisagísticos, devido à sua grande beleza, resistência e praticidade no manuseio. As bromélias são utilizadas tanto na decoração de jardins, como em interiores e hoje já podem ser encontradas à venda em floriculturas, por todo o Brasil. A exportação é 
expressiva, para colecionadores e comerciantes distribuídos por todo o mundo, o que incentiva a coleta ilegal de espécies de maior beleza, acarretando a redução de populações naturais e aumento do número de espécies em risco de extinção (Melo, 1996).

A tradição de cultivo das bromélias na Europa é antiga. Os primeiros estudiosos e apreciadores dessas plantas eram europeus, que realizavam coletas nas Américas e, assim, uma grande quantidade de espécies pode ser encontrada em diversos países da Europa. (Butcher,1995; Samyn \& Thomas, 1995).

Nos Estados Unidos da América do Norte o grande interesse pelo cultivo de bromélias foi demonstrado pela fundação da Bromeliad Society com sede em Orlando, Flórida, o que estimulou a criação de organizações semelhantes em várias partes do mundo. Em 1993, foi criada a Sociedade Brasileira de Bromélias (SBB), sediada no Rio de Janeiro, reunindo interessados na coleção e estudo destas plantas.

A SBB tem estimulado as ações conservacionistas do meio ambiente e apoiado as iniciativas científicas que envolvem o estudo de Bromeliaceae, além de difundir os conhecimentos sobre esta família. (Carvalho, 1994). Outros estados do Brasil possuem um número crescente de estudiosos e colecionadores (Gonzaga, 1997).

Além do extrativismo específico destas plantas, existem três outras ameaças que se agravam com o desenvolvimento econômico: o aumento do uso agrário das regiões que se inicia pelas queimadas (Rocha et al., 1996; Graeff \& Pagani, 1996); a expansão urbana, fruto de um lado do aumento da população e por outro da especulação imobiliária que visam a construção de 
população e por outro da especulação imobiliária que visam a construção de condomínios e complexos turísticos em áreas próximas ao mar. (Leme \& Marigo, 1993). Várias populações nativas de bromélias e outras espécies têm a composição e estrutura das comunidades transformadas por esses agentes impactantes de seus habitat (Nahouw,1994) Segundo critérios que caracterizam o risco de extinção da biota definidos no Livro Vermelho da União Mundial para a Conservação da Natureza (UICN), citado por Carauta e Silva,(1996), os taxons estudados nesse trabalho se classificam como 'dados deficientes', não sendo caracterizados como de alto risco nem de baixo risco, mas com necessidade de futuras pesquisas para a definição correta.

A exemplo de outros países, já existem aqui empresas, que se dedicam exclusivamente à produção massal de mudas de bromélias para fins ornamentais através da utilização de técnicas da cultura de tecidos, visando abastecer os mercados internos e extemos (Zorning, 1996; Luther, 1994).

\subsection{Preservação}

Em face às ameaças a que estão sujeitas as bromélias, estratégias de preservação devem ser adotadas para evitar a extinção de diversas espécies. Dentre as estratégias de conservação atualmente empregadas, destacam-se a criação de reservas ambientais para conservação in situ e os bancos de germoplasma. As reservas ambientais são utilizadas na preservação das espécies, garantindo sua permanência no ambiente natural. Apesar da existência de unidades de conservação, visando a preservação da flora e da 
problemas de manutenção destas unidades, que envolvem falta de fiscalização e ocupação indevida (Sá, 1996).

Os bancos de germoplasma podem ser formados pelo armazenamento de sementes, pela multiplicação dos vegetais em jardins protegidos ou pelo uso de sistemas de micropropagação. No desenvolvimento das metodologias de conservação de espécies ameaçadas, deve-se optar por clones que representem da melhor forma possível, o patrimônio genético da espécie, propiciando uma maior capacidade de adaptação, durante processo de reintrodução (Ramalho et al., 1990).

$\mathrm{O}$ armazenamento de sementes pode ser utilizado com o intuito de preservação para diversas espécies, envolvendo o desenvolvimento de técnicas de secagem e estocagem, de forma que as sementes permaneçam viáveis por um tempo indeterminado. Todavia, algumas espécies possuem sementes recalcitrantes, que perdem rapidamente a viabilidade.

$\mathrm{O}$ estabelecimento de bancos de germoplasma in vitro baseia-se na utilização de técnicas de cultura de tecidos, sendo indicados para a multiplicação de germoplasmas ameaçados ou que tenham ciclos reprodutivos muito longos. Além disso, neste tipo de banco, um grande número de indivíduos pode ser mantido em ambientes livres de patógenos e protegidos de alterações ambientais (Morales et al., 1997).

O desenvolvimento de protocolos de micropropagação para as diversas espécies de bromélias, portanto, torna-se importante, como base para sua conservação in vitro. A utilização dessas metodologias para espécies ameaçadas pode ainda resultar na produção de mudas em larga escala para abastecer o mercado, desencorajando o comércio clandestino e 
ilegal dos extrativistas (Luther, 1994; Fay \& May, 1990; Sharma \& Chandel, 1992; Martin \& Perez, 1993).

\subsection{Cultura de tecidos de bromélias}

A cultura de tecidos vegetais abrange a cultura de protoplastos, células, tecidos e órgãos, em condições assépticas. A obtenção de vegetais através da cultura de tecidos é denominada propagação in vitro ou micropropagação (Grattaplaglia \& Machado, 1990).

A possibilidade de obtenção de plantas completas a partir da cultura de tecidos resulta da capacidade que possuem as células somáticas vegetais de, sob certas condições, voltar a dividir-se, sofrendo desdiferenciação, seguida de rediferenciação em outros tipos celulares (Grattaplaglia \& Machado, 1990).

A multiplicação de bromélia obtida in vitro é geralmente muito superior aquela conseguida in vivo (Mercier \& Kerbauy, 1995; Pierik, 1984).

Os primeiros trabalhos com bromélias iniciaram-se na década de 70 . Jones \& Murashige (1974), utilizando pontas de raízes inoculadas em meio de cultura Murashige-Skoog (MS) suplementado com ANA (ácido $\alpha$ naftalenoacético) e IBA (ácido indol-3-butírico), observaram o desenvolvimento in vitro de Aechmea fasciata. Esse método foi testado em outros 19 gêneros de Bromeliaceae, tendo sido obtidas respostas com Ananas comosus, Cryptanthus bivitattus, Cryptanthus start e Cryptbergia meadii (Cryptanthus beuckeri $x$ Bilbergia nutans). A partir desse trabalho, outros pesquisadores têm-se dedicado ao estabelecimento de protocolos para 
outros pesquisadores têm-se dedicado ao estabelecimento de protocolos para regeneração e propagação in vitro de Bromeliaceae, com a utilização de diferentes explantes e combinações de reguladores de crescimento.

O gênero Ananas tem sido o mais estudado pela sua importância econômica. Cultivares de abacaxi (Ananas cosmosus L. Merr.) apresentam respostas positivas de regeneração na presença dos reguladores BAP, IBA, ANA e Cinetina (Mathews \& Rangan, 1979; Zepeda \& Sagawa, 1982; Fichet, 1990 a e 1990 b; Hirimburegama \& Wijesinghe, 1992;Kiss et al. 1995; Pannetier \& Lanaud, 1976).

A consulta bibliográfica efetuada resultou nos trabalhos listados no quadro 1, relativos ao uso de técnicas de cultura de tecidos com objetivo de micropropagação de diversas espécies de bromélias, excetuando-se o gênero Ananas. Os explantes, os meios e reguladores de crescimento induziram a diferentes respostas. Foi adotada a ordem cronológica para a composição deste quadro.

Nenhumas das três espécies da presente pesquisa, Neoregelia crtenta, Cryptanthus sinuosus e Quesnelia arvensis, segundo a bibliografia consultada, foi estudada sob os aspectos aqui abordados.

O processo de micropropagação tem como um dos seus principais problemas a passagem da planta in vitro para condições ex vitro (Grout, 1975; Donnelly et al., 1985 e Zimmerman, 1988).

$\mathrm{O}$ conhecimento de transformações fisiológicas e histológicas, que caracterizam a mudança de ambiente, pode vir a auxiliar o controle dos fatores que provocam dificuldade na aclimatação de plantas (Brainerd et al, 
Quadro 1. Cultura de tecidos de algumas bromélias

\begin{tabular}{|c|c|c|c|c|c|}
\hline Espécie & \begin{tabular}{|c|} 
Reguladores de \\
Crescimento
\end{tabular} & Meio básico & Explantes & $\begin{array}{c}\text { Respostas } \\
\text { Morfogênicas }\end{array}$ & Referências \\
\hline $\begin{array}{l}\text { Aechmea fasciata } \\
\text { (Lindley)Baker } \\
\\
\text { Cryptanthus } \\
\text { bivitathus ( Regal) } \\
\text { Dyckia sulphurea } \\
\text { (C. Koch) } \\
\\
\text { Cryptbergia } \\
\text { meadii(hibrido) } \\
\text { Guzmania sp. }\end{array}$ & $\begin{array}{l}\text { ANA } \\
\text { IBA } \\
\text { IAA }\end{array}$ & MS & $\begin{array}{c}\text { ápices } \\
\text { caulinares }\end{array}$ & brotos & $\begin{array}{c}\text { Jones \& } \\
\text { Murashige, } \\
1974\end{array}$ \\
\hline Tillandsioideae & auxinas & MS & raízes & $\begin{array}{l}\text { desenvolvimen- } \\
\text { to radicular }\end{array}$ & $\begin{array}{c}\text { Zimer \& } \\
\text { Pieper, } 1976\end{array}$ \\
\hline $\begin{array}{l}\text { Tillandsia } \\
\text { polystachya } \\
\text { Vriesea } \\
\text { heliconioides } \\
\text { V. splendens } \\
\end{array}$ & $\begin{array}{l}\text { auxinas } \\
\text { citocininas } \\
\text { giberelinas }\end{array}$ & Knudson & sementes & $\begin{array}{c}\text { multiplicação } \\
\text { de brotos }\end{array}$ & $\begin{array}{c}\text { Mekerg, } \\
1977\end{array}$ \\
\hline $\begin{array}{l}\text { Cryptanthus } \\
\text { bivitattus }\end{array}$ & $\begin{array}{c}\text { cinetina } \\
2 \mathrm{mg} / \mathrm{L} \mathrm{e} \mathrm{IAA} \\
2 \mathrm{mg} / \mathrm{L}\end{array}$ & $\overline{M S}$ & $\begin{array}{l}\text { gemas de } \\
\text { tecido } \\
\text { caulinar }\end{array}$ & $\begin{array}{l}\text { proliferação de } \\
\text { gemas }\end{array}$ & $\begin{array}{c}\text { Davidson \& } \\
\text { Donnan, } \\
1977\end{array}$ \\
\hline $\begin{array}{c}\text { Quesnelia } \\
\text { quesneliana } \\
\text { (Brongn.) L. B. } \\
\text { Smith } \\
\text { Vriesea poelmannii } \\
\text { (Lindl.) } \\
\end{array}$ & & MS líquido & $\begin{array}{l}\text { gemas } \\
\text { laterais }\end{array}$ & $\begin{array}{c}\text { gemas } \\
\text { adventícias }\end{array}$ & $\begin{array}{c}\text { Hosoki \& } \\
\text { Asahira, } \\
1980\end{array}$ \\
\hline $\begin{array}{l}\text { Aechmea fasciata } \\
\text { (Lindl.)Baker. } \\
\text { Guzmania } \text { ssp }\end{array}$ & $\begin{array}{c}0,3 \mathrm{mg} / \mathrm{L} \mathrm{de} \\
\mathrm{BA}\end{array}$ & MS líquido & $\begin{array}{c}\text { estremidades } \\
\text { folhas }\end{array}$ & $\begin{array}{c}\text { formação de } \\
\text { plântulas, } \\
\text { gemas axilares }\end{array}$ & $\begin{array}{c}\text { Pierik \& } \\
\text { Steegmans, } \\
1984\end{array}$ \\
\hline $\begin{array}{c}\text { Aechmea } \\
\text { victoriana } \mathrm{L} . \mathrm{B} . \\
\text { Foster } \\
\text { Aechmea dactylina } \\
\text { Bal. } \\
\end{array}$ & $\begin{array}{c}2 \mathrm{mg} / \mathrm{L} \text { de BA } \\
2 \mathrm{mg} / \mathrm{L} \mathrm{IAA}\end{array}$ & MS líquido & plântulas & brotos laterais & $\begin{array}{l}\text { Dijck et al., } \\
1988\end{array}$ \\
\hline $\begin{array}{c}\text { Tillandsia cyanea } \\
\text { (Lindl.) }\end{array}$ & $\begin{array}{c}1,0 \mathrm{mg} / \mathrm{L} \mathrm{de} \\
\text { BA 0,01 mg/L } \\
\text { ANA }\end{array}$ & MS líquido & $\begin{array}{c}\text { extremidades } \\
\text { de folhas }\end{array}$ & brotos & $\begin{array}{c}\text { Pierik \& } \\
\text { Sprenkels, } \\
1988\end{array}$ \\
\hline
\end{tabular}


Continuação do Quadro 1

\begin{tabular}{|c|c|c|c|c|c|}
\hline $\begin{array}{l}\text { Tillandisia } \mathrm{sp} \\
\text { Vriesea } \mathrm{sp} . \\
\text { Puya mirabilis }\end{array}$ & $\begin{array}{c}\text { BA } \\
\text { ANA } \\
\text { cinetina }\end{array}$ & RM & $\begin{array}{c}\text { folhas } \\
\text { cortadas } \\
\text { verticalmente }\end{array}$ & $\begin{array}{l}\text { gemas, brotos } \\
\text { adventícios }\end{array}$ & $\begin{array}{c}\text { Kukulczanka } \\
\text { \& Czastka, } \\
1989 .\end{array}$ \\
\hline $\begin{array}{c}\text { Neoregelia } \\
\text { caroline (Beer) L. } \\
\text { B. Smith }\end{array}$ & $\begin{array}{c}0,2 \text { de ANA e } \\
0,2 \text { de BA }\end{array}$ & MS líquido & $\begin{array}{l}\text { meristema, } \\
\text { primórdios } \\
\text { foliares } \\
\end{array}$ & plântulas & $\begin{array}{l}\text { Tombolato } \\
\text { et al., } 1991\end{array}$ \\
\hline $\begin{array}{l}\text { Vriesea fosteriana } \\
\quad \text { (L.B. Smith) }\end{array}$ & $\begin{array}{l}0,5 \mathrm{mg} / \mathrm{L} \text { ANA } \\
2,0 \mathrm{mg} / \mathrm{L} \text { BAP }\end{array}$ & $\mathrm{KC}$ & $\begin{array}{c}\text { partes basais } \\
\text { de folhas } \\
\text { isoladas }\end{array}$ & gemas & $\begin{array}{c}\text { Mercier \& } \\
\text { Kerbauy, } \\
1992\end{array}$ \\
\hline $\begin{array}{c}\text { Dyckia macedoi } \\
\text { (L.B. Smith) }\end{array}$ & $\begin{array}{l}\text { ANA } 0,1 \mathrm{mg} / \mathrm{L} \\
\text { e BAP } 5 \mathrm{mg} / \mathrm{L}\end{array}$ & $\mathrm{KC}$ & folhas & $\begin{array}{l}9 \text { gemas por } \\
\text { folhas }\end{array}$ & $\begin{array}{l}\text { Mercier \& } \\
\text { Kerbauy, } \\
1993\end{array}$ \\
\hline $\begin{array}{l}\text { Aechmea fasciata } \\
\text { (Lindl) Baker }\end{array}$ & & MS & folhas & calos & $\begin{array}{c}\text { Vinterhalter } \\
\& \\
\text { Vinterhalter, } \\
1994 \\
\end{array}$ \\
\hline $\begin{array}{c}\text { Vriesea } \\
\text { hieroglyphica } \\
\text { (Carriere) } \\
\text { E.Morren }\end{array}$ & $\begin{array}{c}2 \mathrm{mg} / \mathrm{L}^{-1} \mathrm{BAP} \\
0,5 \mathrm{mg} / \mathrm{L} \\
\mathrm{ANA}\end{array}$ & $\mathrm{KC}$ & Folhas & gemas & $\begin{array}{l}\text { Mercier \& } \\
\text { Kerbauy, } \\
1994\end{array}$ \\
\hline $\begin{array}{c}\text { Vriesea } \\
\text { hieroglyphica } \\
\text { Vriesea fosteriana }\end{array}$ & $\begin{array}{l}0,5 \mathrm{mg} / \mathrm{L} \text { ANA } \\
\text { e } 2 \mathrm{mg} / \mathrm{L} \text { BAP }\end{array}$ & $\mathrm{KC}$ & Folhas & $\begin{array}{l}25 \text { e } 15,2 \\
\text { gemas por } \\
\text { explantes }\end{array}$ & $\begin{array}{c}\text { Mercier \& } \\
\text { Kerbauy, } \\
1995\end{array}$ \\
\hline
\end{tabular}




\section{REGENERAÇÃO IN VITRO A PARTIR DE EXPLANTES DE FOLHAS DE Neoregelia cruenta (R. GRAHAM) L. B. SMITH, UMA BROMÉLIA ENDÊMICA DO SUDESTE BRASILEIRO}

\section{Resumo}

Um sistema eficiente de regeneração de plantas foi desenvolvido, para a indução de morfogênese direta de folhas derivadas de plântulas de Neoregelia cruenta, uma bromélia endêmica do sudeste Brasileiro. A brotação ocorreu em meio MS suplementado com diferentes combinações de 6-benzilaminopurina e ácido naftaleno acético, diretamente a partir da base da folha. As respostas in vitro foram influenciadas pela idade das plântulas e combinações hormonais. A melhor taxa de regeneração foi obtida de explantes excisados de plântulas com 7 semanas e cultivados em presença de $22 \mu \mathrm{M}$ BAP e $2,5 \mu \mathrm{M}$ ANA. A conversão de broto para plântula foi mais eficiente em brotos formados em resposta a 4,4 $\mu \mathrm{M}$ BAP e $2,5 \mu \mathrm{M}$ ANA. 


\subsection{Introdução}

O Leste brasileiro e especialmente o Estado do Rio de Jameiro são muito ricos em espécies de bromélias. Em consequência do aumento da população humana, os ecossistemas costeiros desta região estão sendo degradados a ritmo acelerado. Tendo em vista que várias bromélias são altamente endêmicas, algumas podem ser perdidas irreversivelmente devido à destruição natural de seus habitats (Leme \& Marigo, 1993).

Neoregelia cruenta é uma bromélia endêmica encontrada exclusivamente em regiões de restinga do Rio de Janeiro (Leme, 1993). Como em outras espécies da família, sua roseta do tipo tanque, forma um micro habitat para diversos grupos de organismos, conferindo um importante papel ecológico a esta espécie na manutenção da complexidade e diversidade do ecossistema (Oliveira et al., 1994).

Além disso, é considerada ao longo da sucessão ecológica uma espécie pioneira. $N$. cruenta coloniza a areia totalmente descoberta, causando o acúmulo de material orgânico que altera o $\mathrm{pH}$ do solo e assim propicia o desenvolvimento de outras espécies vegetais. Com a sombra ocasionada pelo crescimento de arbustos, estas bromélias heliófilas crescem continuamente para a periferia da ilha de vegetação expandindo-a (Hay \& Lacerda, 1980; Leme, 1983). 
$N$. cruenta é comumente usada em projetos paisagísticos devido à beleza de suas folhas, com cerca de $70 \mathrm{~cm}$ de comprimento e pontas vermelhas (Figura 1A). Apesar de ser uma espécie de bromélia comum na restinga, pode ser considerada como ameaçada devido à intensa pressão antrópica sob a qual se encontra seu habitat natural. Alem disso, ocorrem sistematicamente coletas ilegais para atender ao mercado de plantas ornamentais e para projetos paisagísticos.

Devido a estes problemas, são necessários esforços para enfrentar os riscos a que está espécie esta submetida. Este trabalho tem como objetivo desenvolver uma metodologia que pode vir a ser um meio alternativo de produção para suprir o mercado e uso em programas de reintrodução de áreas impactadas. Como a conservação de um grande número de espécies ameaçadas tem sido alcançada através do uso de técnicas de micropropagação (Fay \& May, 1990; Sharma \& Chandel, 1992; Martin \& Pérez, 1993), esta metodologia também fornece a base para o estabelecimento do sistemas de conservação in vitro para $N$. cruenta. 


\subsection{Material e Métodos}

\subsubsection{Meio de cultura e condições}

O meio de cultura basal foi composto por sais minerais e vitaminas do meio MS (Murashige \& Skoog, 1962) acrescido de 3\% de sacarose e solidificado com $0,7 \%$ de ágar. $\mathrm{O}$ pH foi ajustado a 5,8 e a adição de reguladores de crescimento 6-benziladenina (BAP) e ácido $\alpha$ naftaleno acético (ANA) efetuada antes da autoclavagem $\left(120^{\circ} \mathrm{C}\right.$ por 15 min.). As culturas foram mantidas em câmara de crescimento a $28 \pm 2^{\circ} \mathrm{C}$ com uma irradiância total de $10 \mathrm{Wm}^{-2}$, proveniente de lâmpadas fluorescentes tipo luz do dia e gro-lux (3:1), sob o regime de 16 horas/luz e 8 horas/escuro.

\subsubsection{Cultura de explantes}

Sementes de $N$. cruenta foram coletadas na Área de Proteção Ambiental de Massambaba no Municipio de Saquarema (Rio de Janeiro). As sementes foram desinfectadas superficialmente em $70 \%$ de etanol, durante 1 minuto, seguido pela imersão em $5 \%$ de hipoclorito de sódio acrescido de 0,01\% Tween-80, por 30 minutos, com agitação. Após três lavagens com água destilada esterilizada, as sementes foram inoculadas em meio MS sem reguladores de crescimento (MSO) para germinação. As plântulas foram subcultivadas para o mesmo meio, após 14 semanas. Folhas inteiras $(2$ a $3 \mathrm{~cm}$ de comprimento) e o caule remanescente contendo gemas axilares foram 
excisados de plântulas depois de 7,14 e 24 semanas de inoculadas para análise da idade ótima do tecido. Quatro concentrações de BAP $(2,2 ; 4,4$; $8,8$ e $22 \mu \mathrm{M})$ e quatro concentrações de ANA $(0 ; 0,5 ; 1 ; 2,5 \mu \mathrm{M})$ foram usadas em todas as combinações, visando determinar a concentração ótima dos reguladores de crescimento.

As subculturas foram efetuadas bimensalmente, durante oito meses. A eficiência de regeneração foi calculada, considerando-se a percentagem de explantes que regeneraram brotos e o número médio de brotos e plântulas produzidos por explante. $\mathrm{O}$ número de brotos formados por explante foi avaliado durante 8 meses e aqueles com o comprimento mínimo de $1 \mathrm{~cm}$ foram transferidos para MSO para enraizamento. Plântulas foram transplantadas para potes contendo mistura do substrato Plantmax ${ }^{\circledR}$ Eucatex e areia (1:1) e mantidas em área sombreada por Sombrite ${ }^{\circledR}$ com $50 \%$ de redução da luz solar. Cada experimento se constitui de 15 repetições, tendo sido realizados dois experimentos. Os dados foram analisados usando o teste de t-Student ao nível de 0,05 de significância entre as médias. Este teste de comparação de médias foi adotado após análise de variância. 


\subsection{Resultados e Discussão}

\subsubsection{Germinação de sementes}

A germinação de sementes ocorreu três semanas após a inoculação em meio MS. A taxa de germinação foi de $74,3 \%$ e cada semente originou somente uma plântula. Ao contrário do que foi relatado por Mercier \& Kerbauy (1995), que utilizaram meio Knudson sólido para a germinação de sementes de Vriesea hieroglyphica, não foi observado poliembrionia induzida pelo meio de cultura no presente trabalho.

\subsubsection{Regeneração de brotos a partir de gemas axilares}

O desenvolvimento de gemas axilares em explantes caulinares foi muito baixo em todas as concentrações de reguladores de crescimento testadas, tanto em relação à percentagem de regeneração, quanto ao número de brotos por explante. A mortalidade de explantes foi alta, provavelmente devido à significativa taxa de oxidação.

Pesquisas adicionais estão em curso para determinar as necessidades específicas deste explante, através de cultura em meio líquido. Trabalhos com outras espécies de bromélias demonstraram que culturas líquidas induzem eficientemente a regeneração de brotos a partir de gemas axilares (Hosoki \& Asahira, 1980; Kukulczanka \& Czastka, 1984; Pierik \& 
axilares (Hosoki \& Asahira, 1980; Kukulczanka \& Czastka, 1984; Pierik \& Steegmans, 1984). Resultados preliminares indicaram que este tipo de cultura evita a oxidação do explante, indicando uma boa alternativa para a indução da regeneração explantes caulinares de $N$. cruenta.

\subsubsection{Regeneração de explantes de folhas}

A proliferação de gemas adventícias foi evidente na base de explantes foliares em 3 a 4 semanas após o início da cultura. Brotos originaram-se diretamente das protuberâncias formadas no corte feito na base da folha (Fig. 1B) e não foi observada a fase intermediária de calo.

A formação de gemas na base de explante foliar tem sido descrita em outras espécies de bromélias (Hosoki \& Asahira, 1980; Vinterhalter \& Vinterhalter, 1994) e o desenvolvimento de protuberâncias na base das folhas antes da formação de gemas foi também encontrada em Vriesea fosteriana (Mercier \& Kerbany, 1992) e Dyckia macedoi (Mercier \& Kerbauy, 1993).

Ocorreu regeneração de brotos em todas as combinações de reguladores de crescimento, independente da idade de tecido. Entretanto a percentagem de regeneração e o número médio de brotos produzidos por explante foram inversamente correlacionado com a idade da planta doadora. A percentagem máxima de regeneração em folhas excisadas de seedlings com 7 semanas foi de $64 \%$ em resposta a $22 \mu \mathrm{M}$ BAP combinado com $2,5 \mu \mathrm{M}$ ANA, enquanto tecidos mais velhos apresentaram taxas de 22 a $47 \%$. Os primeiros brotos foram observados após 5 semanas e a produção máxima de brotos por explante foi também observada em seedlings de 7 semanas, em 
resposta a $22 \mu \mathrm{M}$ BAP e $2,5 \mu \mathrm{M}$ ANA (Tabela 1, figura 1C). As melhores taxas de formação de brotos a partir de folhas de 7 semanas foram observadas somente em presença de altas concentrações de auxina testadas $(2,5 \mu \mathrm{M}$ ANA). O aumento das taxas de regeneração de tecidos jovens tem sido registrado em outras espécies. (Baker \& Bhatia, 1993). É possível que os novos brotos originem-se de meristemas axilares com alto potencial de formação de gemas na base da folha excisada da planta doadora (Hosoki \& Asahira, 1980; Kukulczanka \& Czastka, 1989).

O enraizamento de brotos ocorreu com facilidade após a transferência para MSO. Mudas foram fenotipicamente normais e não necessitaram de nenhum tratamento contra dessecação, antes de transferência para a casa de vegetação. O número de brotos que atingiram mais de $1 \mathrm{~cm}$ de comprimento foi significativamente mais alto na presença de 4,4 $\mu \mathrm{M}$ BAP acrescido de 2,5 $\mu \mathrm{M}$ ANA, resultando em uma percentagem de conversão de 79 \%. Ao contrário, na combinação hormonal que induziu a produção máxima de brotos $(22 \mu \mathrm{M}$ BAP e $2,5 \mu \mathrm{M}$ ANA), somente $26 \%$ dos brotos apresentaram tamanho adequado para serem transferidos para o meio de enraizamento não ocorreu surgimento e crescimento de brotos laterais durante o enraizamento dos brotos em meio MSO.

O surgimento de brotos laterais foi correlacionado à produção de etileno em meio de cultura suplementado por IAA e BAP, em Aechmea Dijck et al., 1988. Este efeito foi atribuído a ação sinergística da citocinina e auxinas sobre a síntese de ACC-sintase (Dijck et al., 1988). Isto está em contraste com o que ocorre em outras espécies de bromélias, como 
Cryptanthus sinuosus, que não requer a presença de reguladores exógenos para emitir gemas laterais (Dados apresentados no capitulo 4 desta tese).

Os valores representados na tabela 1 referem-se ao período de 8 meses de observação. Entretanto, uma intensa multiplicação de brotos continuou a ocorrer por três meses após a última transferência dos brotos para a formação de raizes (dados não apresentados).

A conservação in vitro de espécies ameaçadas, através da regeneração a partir de folhas derivadas de seedlings jovens apresenta várias vantagens, quando comparada aos métodos que envolvem a cultura de meristema apical ou gemas laterais. Primeiro, a utilização de seedlings, como a fonte de tecidos propicia a representação de uma maior variabilidade genética, sem a necessidade de sacríficio da planta inteira. Segundo, a desinfecção do explante não é requerida, porque são obtidos dos seedlings crescidos, sob condições assépticas. Terceiro, o uso de tecidos jovens pode reduzir a frequência de variação somaclonal (Mercier \& Kerbauy, 1993).

A propagação com base nos experimentos deste trabalho resultou em uma alta eficiência de produção de plantas, propiciando uma média de propagação de cerca de 450 plantas por ano, a partir de cada semente. Assim, este método pode também tanto ser empregado na propagação em larga quantidade como em programas de conservação in vitro. Apesar de não ser recomendada para a propagação de clones selecionados, a metodologia da propagação de $N$. cruenta, baseada na utilização de plântulas como material inicial, pode-se prover o mercado de espécies ornamentais, reduzindo, assim, a necessidade de extrativismo. 
Tabela 1: Efeito da idade do explante e diferentes combinações de BAP/ANA na frequência de regeneração e número de brotos e plântulas completas por explantes de folha de N. cruenta.

\begin{tabular}{cclll}
\hline $\begin{array}{c}\text { Combinações } \\
(\mu \mathrm{M})\end{array}$ & $\begin{array}{c}\text { Explantes } \\
\text { responsivos } \\
(\%)\end{array}$ & $\begin{array}{l}\text { Número } \\
\text { brotos/explante }\end{array}$ & $\begin{array}{l}\text { médio } \\
\text { plântulas/explante }\end{array}$ & $\begin{array}{c}\% \text { de } \\
\text { conversão }\end{array}$ \\
BAP $\quad$ ANA & & & & \\
\hline
\end{tabular}

\begin{tabular}{|c|c|c|c|c|c|}
\hline \multicolumn{6}{|c|}{ Explantes com 7 semanas } \\
\hline \multirow{3}{*}{4,4} & 0 & 50 & $17,5 \pm 4,0^{d}$ & $6,2 \pm 2,4^{\mathrm{a}}$ & 35,4 \\
\hline & 1 & 55 & $20,1 \pm 4,2^{\mathrm{e}}$ & $10,2 \pm 3,3^{c}$ & 50,7 \\
\hline & 2.5 & 56 & $32,2 \pm 4,0^{\mathrm{g}}$ & $21,7 \pm 3,8^{\mathrm{d}}$ & 67,3 \\
\hline \multirow{3}{*}{8,8} & 0 & 50 & $15,0 \pm 4,1^{d}$ & $4,9 \pm 2,1^{a}$ & 32,6 \\
\hline & 1 & 58 & $25,8 \pm 4,5^{f}$ & $9,7 \pm 1,8^{\mathrm{c}}$ & 37,5 \\
\hline & 2.5 & 48 & $24,8 \pm 3,0^{f}$ & $19,6 \pm 2,9^{d}$ & 79,0 \\
\hline \multirow{3}{*}{22} & 0 & 32 & $18,7 \pm 2,4^{\mathrm{e}}$ & $10,3 \pm 2,0^{c}$ & 55,0 \\
\hline & 1 & 55 & $18,5 \pm 1,9^{\mathrm{e}}$ & $11,1 \pm 1,4^{\mathrm{c}}$ & 60,0 \\
\hline & 2.5 & 64 & $50,3 \pm 6,2^{h}$ & $13,0 \pm 2,4^{d}$ & 25,8 \\
\hline \multicolumn{6}{|c|}{ Explantes com 14 semanas } \\
\hline \multirow{3}{*}{4.4} & 0 & 35 & $9,2 \pm 1,2^{b}$ & $5,5 \pm 1,2^{a}$ & 59,7 \\
\hline & 1 & 40 & $15,0 \pm 1,4^{d}$ & $9,0 \pm 1,3^{c}$ & 60,0 \\
\hline & 2.5 & 40 & $16,2 \pm 1,5^{\mathrm{d}}$ & $11,0 \pm 1,6^{\mathrm{c}}$ & 67,9 \\
\hline \multirow{3}{*}{8.8} & 0 & 37 & $9,3 \pm 1,7^{b}$ & $5,0 \pm 1,4^{a}$ & 53,7 \\
\hline & 1 & 45 & $14,0 \pm 1,6^{\mathrm{d}}$ & $12,0 \pm 2,0^{\mathrm{c}}$ & 85,7 \\
\hline & 2.5 & 40 & $16,0 \pm 1,8^{\mathrm{d}}$ & $11,0 \pm 1,8^{\mathrm{c}}$ & 68,7 \\
\hline \multirow{3}{*}{22} & 0 & 29 & $12,5 \pm 1,6^{\mathrm{c}}$ & $7,0 \pm 1,3^{\mathrm{a}}$ & 56,0 \\
\hline & 1 & 47 & $11,8 \pm 3,2^{c}$ & $5,9 \pm 1,7^{\mathrm{a}}$ & 50,0 \\
\hline & 2.5 & 39 & $15,6 \pm 1,5^{d}$ & $8,0 \pm 1,6^{a}$ & 51,2 \\
\hline \multicolumn{6}{|c|}{ Explantes com 24 semanas } \\
\hline \multirow{3}{*}{4.4} & 0 & 25 & $4,2 \pm 1,1^{\mathrm{a}}$ & $3,0 \pm 1,2^{b}$ & 71,4 \\
\hline & 1 & 29 & $10,5 \pm 1,9^{b}$ & $6,0 \pm 1,3^{\mathrm{a}}$ & 57,1 \\
\hline & 2,5 & 32 & $11,4 \pm 1,1^{b}$ & $6,0 \pm 1,2^{\mathrm{a}}$ & 52,6 \\
\hline \multirow{3}{*}{8.8} & 0 & 22 & $7,0 \pm 1,4^{a}$ & $2,0 \pm 1,4^{b}$ & 28,5 \\
\hline & 1 & 33 & $10,6 \pm 1,7^{b}$ & $7,0 \pm 1,4^{\mathrm{a}}$ & 66.0 \\
\hline & 2,5 & 32 & $12,2 \pm 1,4^{\mathrm{c}}$ & $7,0 \pm 1,8^{\mathrm{a}}$ & 57,3 \\
\hline \multirow{3}{*}{22} & 0 & 22 & $8,0 \pm 1,4^{b}$ & $4,0 \pm 1,4^{b}$ & 50 \\
\hline & 1 & 32 & $9,6 \pm 1,8^{b}$ & $3,0 \pm 1,4^{b}$ & 31,2 \\
\hline & 2,5 & 29 & $11,0 \pm 1,5^{b}$ & $4,0 \pm 1,6^{b}$ & 36,3 \\
\hline
\end{tabular}

( \pm )Desvio Padrão.a-g em cada coluna, médias seguidas da mesma letra não tem diferenças significativas a nível de $\alpha \leq 0.05$ através do teste $t$ (Student). 

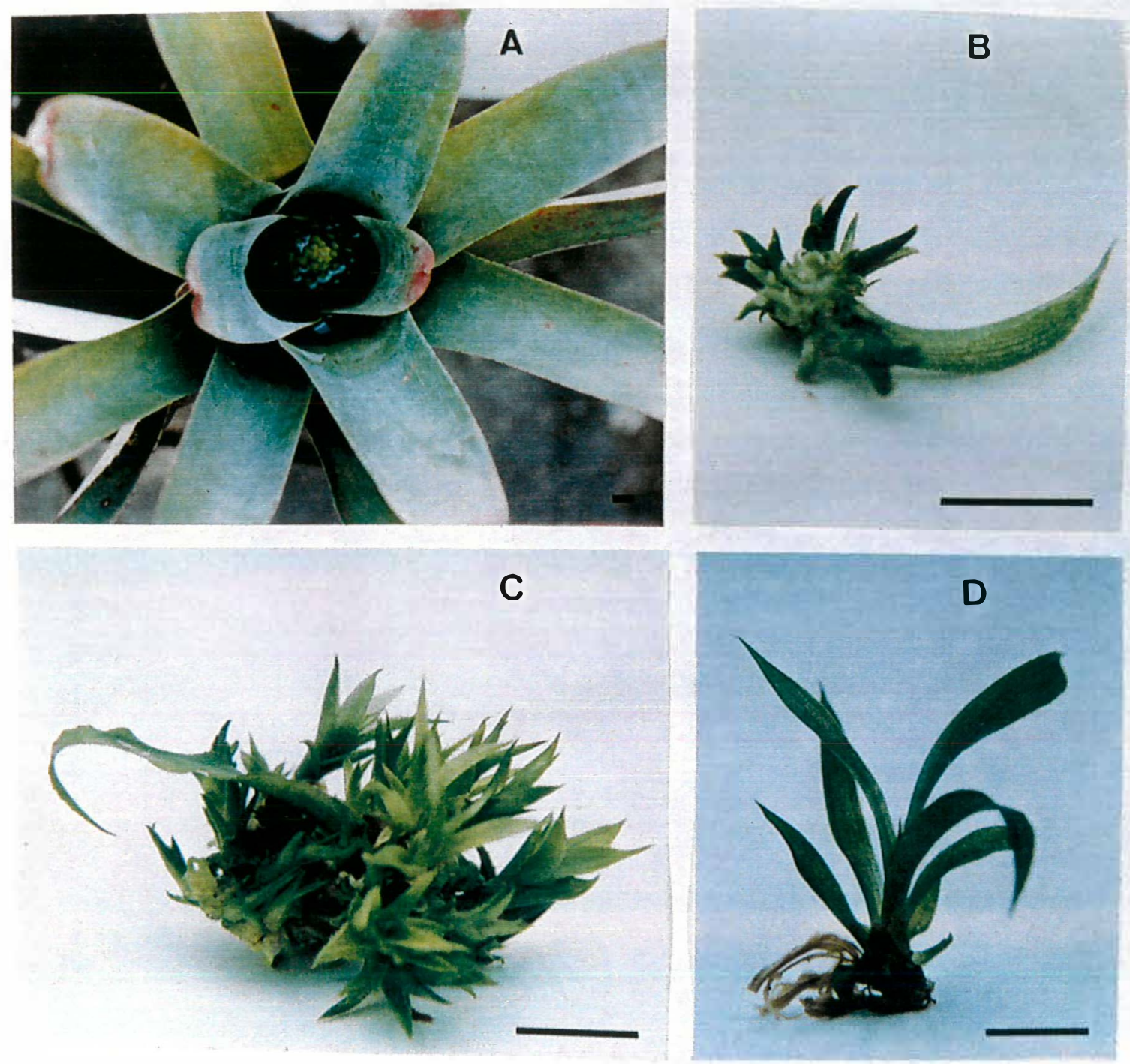

Figura 1 - Regeneração in vitro de $N$. cruenta A- Planta adulta em casa de vegetação. B- Protuberância na base da folha onde se formam brotos e gemas após 5 semanas de cultura em meio MS suplementado com $22 \mu \mathrm{M}$ BAP e 2,5 $\mu \mathrm{M}$ ANA.C- Multibrotação após 4 meses de cultura. D- Plântula enraizada 3 meses após a excisão do broto e inoculação em meio MSO. $($ barra $=1 \mathrm{~cm})$ 


\section{PROPAGAÇÃO CLONAL DE Cryptanthus sinuosus L.B. SMITH, UMA ESPÉCIE DE BROMÉLIA ESTOLONÍFERA E ENDÊMICA DO RIO DE JANEIRO, BRASIL.}

\section{Resumo}

O potencial regenerativo de estolões de $C$. sinuosus foi avaliado visando o estabelecimento de um protocolo de propagação clonal. Os estolões foram retirados de espécimes mantidos em casa de vegetação e inoculados em meio MS solidificado. Os brotos desenvolvidos a partir dos estolões foram transferidos para meio MS ou usados como doadores de explantes de folha ou de caule, que foram inoculados em meio MS suplementado com diferentes concentrações de 6-benzilaminopurina (BAP) ou tidiazuron (TDZ). A cultura de explantes de folhas em presença de $22 \mu \mathrm{M}$ de BAP resultou no aumento na taxa de brotação e formação de mudas. Explantes de caule apresentaram melhor eficiência de regeneração em resposta a 4,4 $\mu \mathrm{M}$ BAP. A capacidade de multiplicação de explantes de folhas e de caules cultivados em meio contendo BAP foi mantida por 
sucessivas subculturas no meio original, durante um período de observação de dois anos. O número de brotos induzidos em resposta às concentrações de TDZ testadas foi significativamente menor do que o encontrado em resposta às concentrações mais eficientes de $\mathrm{BAP}$. Além disso, muitas gemas produzidas em resposta a concentrações de $0,1 \mu \mathrm{M}$ de $\mathrm{TDZ}$ não se desenvolveram em brotos. Brotos regenerados in vitro foram transferidos para meio MS0, onde desenvolveram raízes e partes aéreas além de produzir brotos de forma contínua por dois anos. As mudas foram transferidas para o substrato para o crescimento, sem a necessidade de um período de aclimatização. Não ocorreram fenótipos anormais. 


\subsection{Introdução}

A família Bromeliaceae é caracterizada por um alto nível de especiação e muitas espécies apresentam atualmente um risco de extinção elevado, devido, principalmente, à destruição de seus habitats ocasionada pelo desenvolvimento econômico. Outro fator de risco importante é a extrativismo seletivo objetivando o suprimento do comércio de plantas ornamentais. $\mathrm{O}$ endemismo restrito torna certas espécies mais vulneráveis ao impacto ambiental causado por atividades antrópicas. (Leme \& Marigo, 1993, Mercier \& Kerbauy,1995).

Cryptanthus é um gênero tipicamente brasileiro, encontrado sempre em habitats terrestres ou rupícolas ao longo da costa na região de restinga e na mata Atlântica, bem como na caatinga e restinga. Espécies de Cryptanthus são mais endêmicas do que outros membros da família, provavelmente em consequência da produção de sementes e frutos pesados que não possuem potencial de atração de agentes dispersores (Cândido,1996; Cândido,1995).

Cryptanthus sinuosus foi descrita em 1955, baseada na descrição original de C.undulatus Otto \& Dietrich, nomen illegítimum. Espécie terrestre e endêmica do Estado do Rio de Janeiro, encontrada em afloramentos rochosos no mar bem como na floresta de restinga. A verdadeira identidade de $C$. sinuosus é controversa levando em conta sua 
similaridade com C. aucalis. Por causa da falta de espécies tipo, é muito dificil resolver este problema de forma segura. Os mais recentes estudos examinaram populações sobre rochas, próximas ao município de Cabo Frio, todas estoloníferas, como C.sinuosus. A presença de estolão não é muito comum neste gênero, ocorrendo somente em 3 das 44 espécies consideradas válidas (Cândido,1995).

Este trabalho é parte de um projeto de micropropagação e conservação in vitro de espécies endêmicas de Bromeliaceae do Estado do Rio de Janeiro, Brasil e visa o desenvolvimento de um protocolo de propagação clonal de C.sinuosus, usando estolões como material inicial. Como seu habitat está sofrendo impacto crescente, existe um risco significativo de extinção desta espécie, o qual justifica o estabelecimento de sistemas de conservação in vitro como um modo alternativo de conservação. Além disso, considerando o reduzido tamanho da planta, a produção in vitro de C.sinuosus pode suprir o mercado com uma bromélia apropriada para uso em interiores. 


\subsection{Material e Métodos}

\subsubsection{Condições de cultura}

O meio básico de sais minerais e vitaminas usado foi o MS (Murashige \& Skoog ,1962), com 3\% de sacarose e solidificado com 0,7\% de agar marca Sigma.

$\mathrm{O}$ pH do meio foi ajustado para 5.8 antes da autoclavagem. Adicionaram-se os reguladores de crescimento BAP $(4.4,8.8$ e $22,1 \mu \mathrm{M})$ ou $\operatorname{TDZ}(0,01 ; 0,04 ; 0,07 ; 0,1 ; 0,2 ; 1$ e $10 \mu \mathrm{M})$ antes da esterilização autoclave a $120^{\circ} \mathrm{C}$ a 2 atmosferas de pressão por 15 minutos. As culturas foram mantidas em câmaras de crescimento a $28 \pm 2^{\circ} \mathrm{C}$ com uma irradiação total de $10 \mathrm{Wm}^{2}$ propiciado pelo o uso de lâmpadas fluorescentes tipo luz do dia e lâmpada fluorescente tipo gro-lux (1:3) sob o regime de 16 horas/luz e 8 horas /escuro.

\subsubsection{Cultura do explante}

Exemplares de C. sinuosus coletadas no município Arraial do Cabo (Estado do Rio de Janeiro) foram mantidos em casa de vegetação durante seis semanas (Figura 2A). Antes da retirada, os explantes foram tratados 
com o fungicida Manzate-800 (10mg/L) durante 3 semanas. Para iniciar a cultura, os estolões foram destacados e lavados com água esterelizada e detergente. As brácteas externas foram cortadas e os estolões foram mergulhados em etanol $70 \%$, por 1 minuto seguido de imersão em solução de hipoclorito de sódio a $5 \%$ mais $0.01 \%$ de Tween- 80 , sob agitação por 30 minutos.

Os estolões foram lavados com água destilada esterelizada e após a remoção das regiões oxidadas e inoculados em meio (MSO) sem reguladores de crescimento (segmentos de cerca de $2 \mathrm{~cm}$ de comprimento).

Os brotos produzidos sobre os estolões após 7 semanas (Fig. 2B) foram cortados e transferidos para meio MSO e usados como fonte de explantes em 4 semanas. Folhas internas com cerca de $2 \mathrm{~cm}$ de comprimento e o caule remanescente foram usados como explantes e cultivados em meio MS complementado com diferentes concentrações dos reguladores de crescimento BAP ou TDZ.

As subculturas foram realizadas a cada oito semanas durante oito meses. O número de brotos formados foi monitorado e aqueles que alcançaram mais de $1 \mathrm{~cm}$ de comprimento foram transferidos para MSO para enraizamento. Nesse meio os brotos se desenvolviam ao estágio de plântulas. Algumas dessas plântulas nessas condições produziam mais brotos a partir de sua base.Quando isso acontecia os brotos eram separados e no mesmo meio se desenvolviam em plântulas.

Após este período, as mudas foram transplantadas para potes contendo substrato do tipo Plantmax ${ }^{\mathbb{R}}$ e areia (1:1) e colocadas sob telado com sombreamento de $50 \%$ de luz solar utilizando tela de tipo Sombrite ${ }^{\circledR}$. 
Os experimentos foram repetidos três vezes e vinte explantes foram usados em cada tratamento.

A eficiência de regeneração foi calculada considerando a percentagem de plantas que regeneraram brotos e o número médio de brotos e mudas produzidos por explante. O desvio padrão e a comparação de médias ao nível de significância de $\alpha=0,05$ foi realizado através do teste$\mathrm{t}$ (Student). 


\subsection{Resultados}

Explantes de folhas cultivados em presença de BAP apresentaram multiplicação de brotos axilares desenvolvidos diretamente da base das folhas entre 4 a 5 semanas de cultura (Figura 2C), formando vários outros brotos durante o periodo de observação (Figura 2D). A percentagem de explantes responsivos foi em torno de $40 \%$, independente da concentração de BAP usada (Figura 3A). O número médio de brotos, bem como o de mudas produzidas por explante foi alto em meio suplementado com a concentração de $22 \mu \mathrm{M}$ (figuras $3 \mathrm{C}$ e $3 \mathrm{E}$ ). A resposta de explantes de caule a BAP foi tardia e iniciou-se somente após 6 a 7 semanas de cultura. Uma alta percentagem de explantes responsivos foi observada na mais baixa concentração de BAP testada $(4.4 \mu \mathrm{M})$ (Figura 3A). Explantes cultivados em presença de 4,4 ou $13,2 \mu \mathrm{M}$ produziram número médio brotos semelhantes (figura 3C) e apresentaram continuada produção de brotos durante dois anos de observação. Entretanto, a conversão em mudas foi significativamente $(p<0.05)$ maior em brotos derivados de explantes cultivados em meio suplementado com 4,4 $\mu \mathrm{M}$ BAP (Figura 3E).

Em meio suplementado com TDZ, a percentagem de explantes responsivos foi cerca de $30 \%$ e $80 \%$, a partir de folhas e de caules respectivamente (Figura 3B). Os explantes formaram, inicialmente, 
protuberâncias nas regiões axilares, que originaram numerosas gemas. Apesar de os explantes cultivados em presença de TDZ exibirem alta taxa de indução em todas as concentrações testadas, a maioria das gemas não se desenvolveram em brotos, entre 0,2 e 10 $\mu \mathrm{M}$ (dado não apresentado). $\mathrm{O}$ número médio de brotos e mudas produzido em resposta a concentrações na faixa entre 0,01 e $0,1 \mu \mathrm{M}$ TDZ foi, em geral, baixo, quando comparado ao número obtido em resposta ao BAP. Além disso, os brotos eram menores, apresentaram elevado número de folhas e muitas culturas em TDZ ficaram visivelmente oxidadas após 7 meses de cultura. Mudas derivadas da cultura de explantes ou diretamente dos estolões foram transferidas para MS0, onde desenvolveram raízes, aumentaram em altura e produziram brotos (Figura 2E) por um período de dois anos. Mudas mantidas in vitro foram transferidas para casa de vegetação, sem a necessidade de período de aclimatação e, exceto aquelas formados em presença de $\mathrm{TDZ}$, não mostraram sinais de alterações morfológicas. 


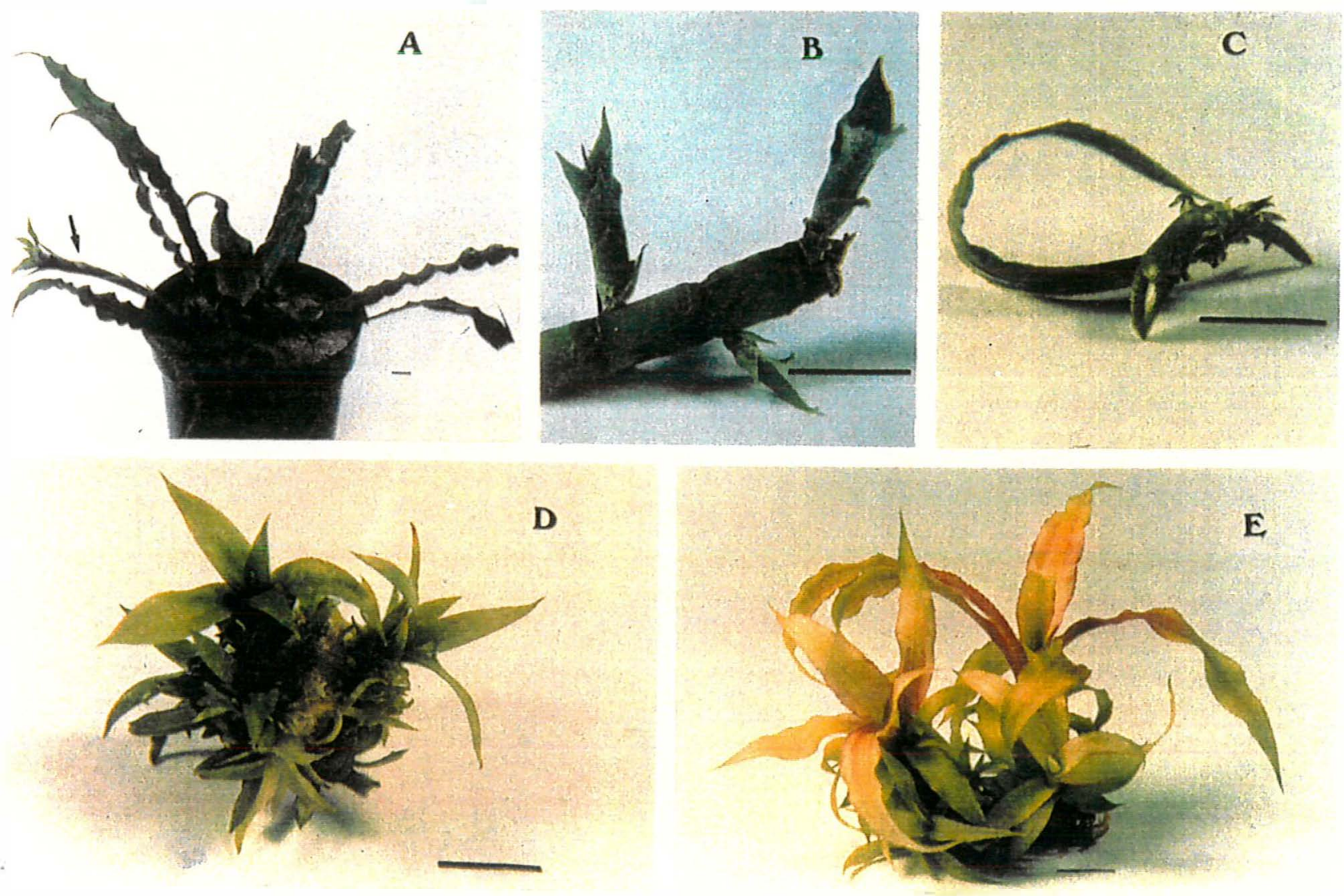

Figura 2 - Regeneração in vitro de C. sinuosus A- planta doadora em casa de vegetação (seta indica o estolão). B- Formação de brotos sobre segmento de estolão de 2,5cm. após 2 semanas de cultura em meio MSO. C- primeiros brotos axilares formados sobre o explante foliar após 4 semanas de sobre meio MS com $22 \mu \mathrm{M}$ BAP. D- Multibrotação formada de explantes foliares após 4 meses de cultura sobre meio MS $+22 \mu \mathrm{M}$ BAP. E- Plântulas após 3 meses de cultura sobre meio MSO. (barra $=1 \mathrm{~cm})$ 


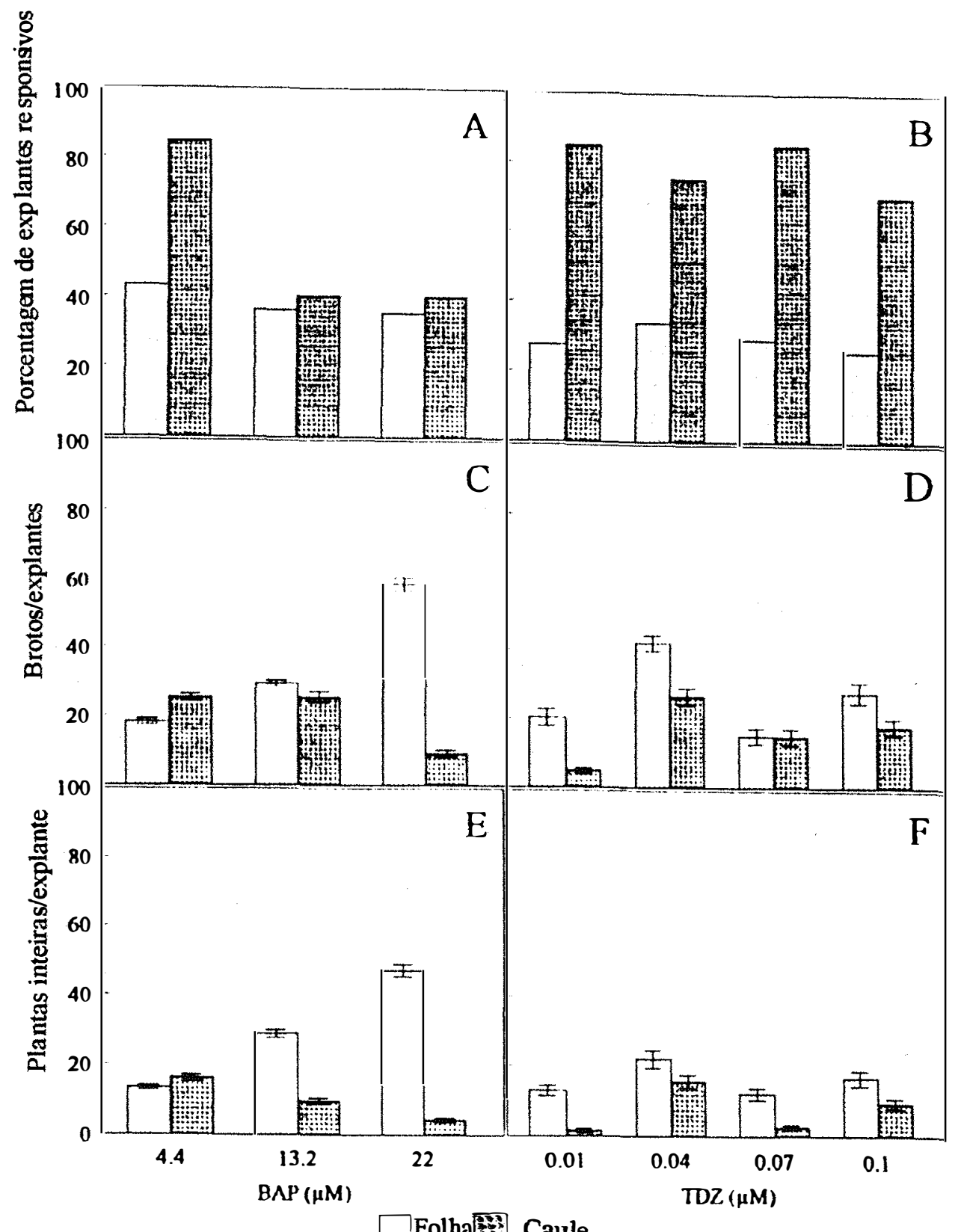

Figura 3 - Regeneração in vitro de $C$. sinuosus a partir de explantes foliares e caulinares, induzida por concentrações de BAP e TDZ.Nos gráficos C,D,E e $\mathrm{F}$ sobre as colunas estão representados os desvios padrões. 


\subsection{Discussão}

No presente trabalho foi descrito um protocolo eficiente de regeneração in vitro para $C$. sinuosus através da multiplicação de gemas axilares usando explantes de folha e caule cultivados em presença de BAP e ausência de auxina. Diversos protocolos de micropropagação de bromélias descritos anteriormente foram baseados no uso de combinações auxinacitocinina. A regeneração de plantas tem sido conseguida por multiplicação de meristemas, utilizando ápices caulinares (Pierik \& Steegmans, 1984; Tombolato et al. 1991; Hinimburegama e Wijesinghe,1992), gemas laterais (Hosoki \& Asahira, 1980; Fitchet-Purnell, 1993; Fitchet, 1990a ; Van Dijck et al., 1988), explantes de folhas (Kukuklczanka \& Czastka,1989; Mercier \& Kerbauy, 1993) e sementes (Mercier \& Kerbauy,1995), bem como via formação de calos de diferentes explantes, como folhas (Vinterhalter \& Vinterhalter, 1994), ápices caulinares (Fitchet,1990) e gemas laterais (Mathews \& Rangan, 1981).

Pelo que se tem conhecimento, este é o primeiro trabalho sobre o uso de TDZ para micropropagação de bromélias. O TDZ é uma $\mathrm{N}^{6}$-fenilureia com alta capacidade de induzir atividade de divisão celular, originariamente usada como desfolhante de algodoeiros (Amdt et al.1976). Tem sido estudado na indução in vitro de respostas morfogênicas, como a indução de 
alta frequência de multibrotação originados diretamente de cultura de sementes (Malik \& Saxena, 1982; Malik et al. 1993), estimulação de embriogênese somática (Huetteman e Preece, 1993), regeneração de brotos adventícios (Turk et al., 1994; Baker \& Bhatia, 1993; Orlikowska \& Dyer, 1993) e crescimento de calos (Orlikowska \& Dyer, 1993). A morfogênese induzida por TDZ foi encontrada em resposta a uma ampla faixa de

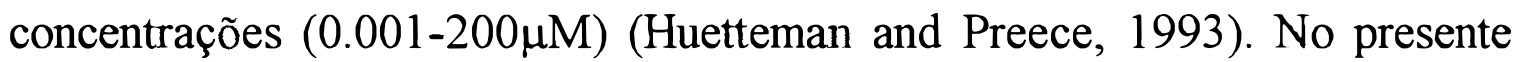
trabalho eficiência de regeneração dos explantes cultivados em presença de TDZ foi induzida na concentração de $0,04 \mu \mathrm{M}$ (Fig. 3B).

O TDZ foi significativamente menos eficiente que o BAP na indução da regenereração de brotos viáveis. A comparação com os resultados obtidos com BAP indicaram que TDZ induzindo explantes foliares mostraram 33\% brotos por explantes e $45 \%$ menos plântulas por explantes. A partir de explantes caulinares a mesma comparação não indicou diferença significativa entre a ação de BAP e TDZ.

De um modo geral como as folhas são mais numerosas como explantes do que os caules, o TDZ pode ser considerado menos eficiente do que o BAP no processo de regeneração aqui apresentado.

Conforme descrito neste protocolo, em concentrações de BAP que induziram a máxima produção a partir de explantes de folhas, cada broto excisado de um estolão (contendo no mínimo 6 folhas) pode potencialmente, originar cerca de 400 plantas, após 8 meses, e continuar a produção por mais dois anos. Considerando que plantas adultas produzem vários estolões e que cada estolão pode ser segmentado em vários explantes de $3 \mathrm{~cm}$, e cada um 
deles originar vários brotos, este método pode ser considerado eficiente para a produção massal.

A micropropagação de espécies de bromélias é comumente obtida a partir da culturas de brotos apicais. O uso desta técnicas em espécies ameaçadas é limitado, devido a dificuldades de obtenção de um grande número de plantas doadoras. Assim, a obtenção de plântulas assépticas através da germinação de sementes in vitro vem sendo recomendada como uma alternativa adequada a cultura de meristemas apicais (Mercier \& Kerbauy, 1995).

Neste trabalho, demonstrou-se a possibilidade do uso de estolões como material de partida como outra estratégia viável. A principal vantagem é que estolões podem ser coletados diretamente no campo ou de um pequeno número de exemplares de casa de vegetação sem dano à planta doadora. Assim, a multiplicação in vitro usando estolões pode ser recomendada para a propagação clonal de bromélias estoloniferas que por sua vez pode ser utilizada comercialmente ou em programa de preservação e reintrodução. 


\section{EFEITO DE CONCENTRAÇÕES DE ANA E BAP NA REGENERAÇÃO DE Cryptanthus sinuosus L.B. SMITH.}

\subsection{Introdução}

Muitos autores utilizaram a combinação ANA e BAP para induzir a brotação a partir de diferentes tipos de explantes, como pode ser observado no quadro 1. Especificamente os trabalhos de Mercier e Kerbauy, 1992,1993,1994 e 1995,Vinterhalter,1994,Kukulczanka e Czastka (1989) e Pierik e Steegmans, 1984 demostraram bons resultados de regeneração de plantas quando explantes foliares foram submetidos a ação destes reguladores de crescimento combinados.

A espectativa ao utilizar estas combinações foi de otimizar os resultados já então obtidos com o uso de BAP e relatados no capítulo 4 . Além disso um estudo histológico se fazia necessário para elucidar o tipo de formação tecidual das protuberâncias que eram observadas, após dois meses de cultura, na base da folha, onde se iniciava a brotação. $\mathrm{Na}$ bibliografia consultada nenhuma espécie de análise desta natureza foi encontrada. Á importância deste estudo basea-se no estabelecimento de técnicas de conservação in vitro de germoplasma desta espécie, pouco estudada até o momento. 
A metodologia aqui desenvolvida pode também ser aplicada na produção massal de mudas, para programas de conservação, reintrodução ou comercialização.

\subsection{Material e Métodos}

As concentrações de reguladores de crescimento usados foram BAP 2,$2 ; 4,4 ; 8,8$ e $22 \mu \mathrm{M}$ combinados com ANA 0,$5 ; 1,0 ; 2,5 \mu \mathrm{M}$.

As condições de cultura e os tipos de explantes foram os mesmos utilizados no capítulo 4 deste trabalho.

\subsubsection{Procedimentos histológicos}

Protuberâncias formadas, após 2 meses de cultura, na base das folhas inoculadas em meio MS suplementado com BAP a $4,4 \mu \mathrm{M}$ e ANA a $0,1 \mu \mathrm{M}$ foram seccionados histologicamente com uso do aparelho Vibraslice (Campden Instruments). As secções tinham a espessura de cerca de $20 \mu \mathrm{m}$, o corante utilizado foi safrablau utilizando a metodologia de Bukatsch (1972). Após imersão na solução corante, a diferenciação foi conseguida com água. A montagem das lâminas foi feita com solução de glicerina 50\%. As microfotografias foram realizadas em microscópio estereoscópico (Olympus). 


\subsection{Resultados e Discussão}

\subsubsection{Estrutura histológica das protuberâncias:}

Em todos os explantes cultivados nos meios com combinações de reguladores de crescimento, houve a formação de uma protuberância na base da folha. Este fenômeno foi observado em N. cruenta, (capítulo 3 desta tese) e em C. sinuosus, (capítulo 4 desta tese). Outros autores também observaram semelhantes formações (Mercier \& Kerbauy; 1993, 1995) e alguns as denominaram como calos (Mathews \& Ragan, 1982).

Os cortes histológicos indicaram que essas estruturas não são compativeis com calos uma vez que existe sistema vascular visivelmente organizado. As regiões mais escuras, no corte, correspondem a tecidos xilemáticos (Figura 4B). Outra evidência de que esta protuberância não apresenta características de calo é a presença de ráfides (Figura 4A). Esta modificação, no início da cultura de explantes foliares de bromélias já foi constatada por Mercier \& Kerbauy (1992) e Mercier \& Kerbauy (1993) porém, na bibliografia pertinente a cultura de tecidos de bromélias, não foi citada nenhuma observação histológica sobre destas protuberâncias. 
Análises histológicas de estágios anteriores do processo poderão elucidar melhor os fenômenos morfogênicos iniciais que dão origem às protuberâncias (Figura. 4).

\subsubsection{Efeito das combinações BAP/ANA}

A resposta morfogênica de explantes foliares, para diversas combinações de BAP e ANA, tem sido descrita em várias espécies de bromélias (Kukulczanka \& Czaska, 1989; Mercier \& Kerbauy, 1993; Vinterhalter \& Vinterhalter, 1994).

A perspectiva fisiológica dos processos celulares associados à morfogênese não é o objetivo central deste trabalho mas, diante de respostas com desvios padrões elevados, torna-se necessário ressaltar algumas citações dos autores a cerca destes processos, para melhor entendimento das variações apresentadas.

Segundo Grattapaglia \& Machado (1990), existem várias indicações de que BAP promove a multiplicação de partes aéreas e indução de gemas adventícias. O aparecimento de gemas adventícias é explicado por Van Amold \& Hawes (1989) como decorrentes de meristemóides originados pela diferenciação de tecidos epidérmicos e sub epidérmicos, ocasionada pela ação de citocininas.

Somente células com receptores específicos são capazes de ligar-se ao BAP recebendo, assim, o estímulo para disparar o processo de morfogênese (Osborne, 1989 e Flinn et al., 1988). 
Estas células existem em diferentes níveis de competência, requerendo períodos variados de exposição para que o agente regulador possa ser reconhecido.

Por outro lado receptores auxínicos e específicos para ANA e outras auxinas já são conhecidos há alguns anos (Batt et al., 1976). A habilidade das auxinas modularem ou dispararem processos biossintéticos nos quais estão incluídos seu efeito morfogênico foi estudada por Jacobsen (1977) e Trewavas (1979). Assim, podem ser citados diferentes fatores endógenos que interagem com um determinado tecido para que o efeito desejado seja atingido.

Folhas provenientes de genótipos diferentes, região em que a folha foi cortada do broto, número de receptores hormonais por célula, tempo de indução da atividade morfogênica, capacidade do tecido foliar absorver água e nutrientes do meio, interações entre hormônios, entre outros, são fatores que devem ser considerados nas análises de respostas heterogêneas (Lakashmanan et al., 1997; Christianson \& Warnick, 1985; Hicks, 1994; Batley \& Lyndan, 1988).

Os explantes mais novos que apresentaram maior eficiência regenerativa também não possuíam homogeneidade de respostas para uma concentração específica de regulador quando comparados com os explantes mais velhos, conforme pôde ser observado no capítulo 3 deste trabalho (Tabela 1).

Nas condições que os experimentos foram conduzidos, os explantes foliares apresentaram um alto potencial de regeneração, principalmente nas concentrações de BAP $8,8 \mu \mathrm{M}$ com ANA 1 e $2,5 \mu \mathrm{M}$ quanto à formação de 
brotos por explante, e BAP $4,4 \mu \mathrm{M}$ com ANA $2,5 \mu \mathrm{M}$ na produção de plântulas por explante, (Tabela 2), por conta da maior conversão do experimento $93,7 \%$.

Comparando esses resultados com os obtidos ao usar somente BAP como indutor da brotação, conforme mostrado no capítulo 4 o uso de todas as combinações BAP/ANA melhoraram bastante a percentagem de explantes responsivos.

Em todas as concentrações de ANA com $4,4 \mu \mathrm{M}$ de BAP o número médio de brotos/explante e plântulas/explante também foi maior comparativamente. Somente os resultados com o uso de $22 \mu \mathrm{M}$ de BAP visto no capítulo 4 superavam os obtidos com a combinação de $22 \mu \mathrm{M}$ BAP combinado com ANA aqui demonstradas.

Sempre que foi usado ANA a $1 \mu \mathrm{M}$ o percentual de explantes responsivos foi menor comparado com os resultados de $0,5 \mu \mathrm{M}$ e $2,5 \mu \mathrm{M}$ de ANA. Mas estas tendências não foram seguidas quanto ao número médio de brotos/explante e na conversão de brotos em plântulas.

Estes resultados credenciam a espécie como um modelo a ser aproveitado para estudo quanto à interação hormônio-célula e efeitos de reguladores nos processos morfogênicos de regeneração a partir de explantes foliares.

Mudas originárias deste processo apresentaram crescimento normal nos seis meses subsequentes, em substrato Plantmax. O único procedimento de aclimatação foi a redução da luz solar a $50 \%$.

Em muitos segmentos de estolões ocorreram brotações duplas ou triplas. Tomando-se 10 folhas destes brotos como explantes, poderíamos 
obter 340 mudas no período de 8 meses, sem retirada de exemplares da natureza.

A variação somaclonal da integridade genética das plantas devido ao processo de culturas de tecido in vitro tem sido bem documentado (Hawbaker et al. 1993; Dahleen et al. 1991).

Componentes de meio de cultura, tipos de explantes e idade da cultura podem contribuir para alterações de material genético que podem ser diagnostrcados rapridamente através da análise de RAPD (Random Amplified Polymorphic DNA) Consoli 1995, Brown et al. 1993 ( in Consoli).

Estudos preliminares para análise da integridade genótica das plântulas através de RAPD(Random Amplified Polymorphic DNA) foram iniciadas estabelecendo uma perspectiva de continuidade desse trabalho.

Finalmente, estudos de conservação in vitro do germoplasma, destas e de outras espécies da família Bromeliaceae, podem ser desenvolvidos a partir do conhecimento destas potencialidades. 

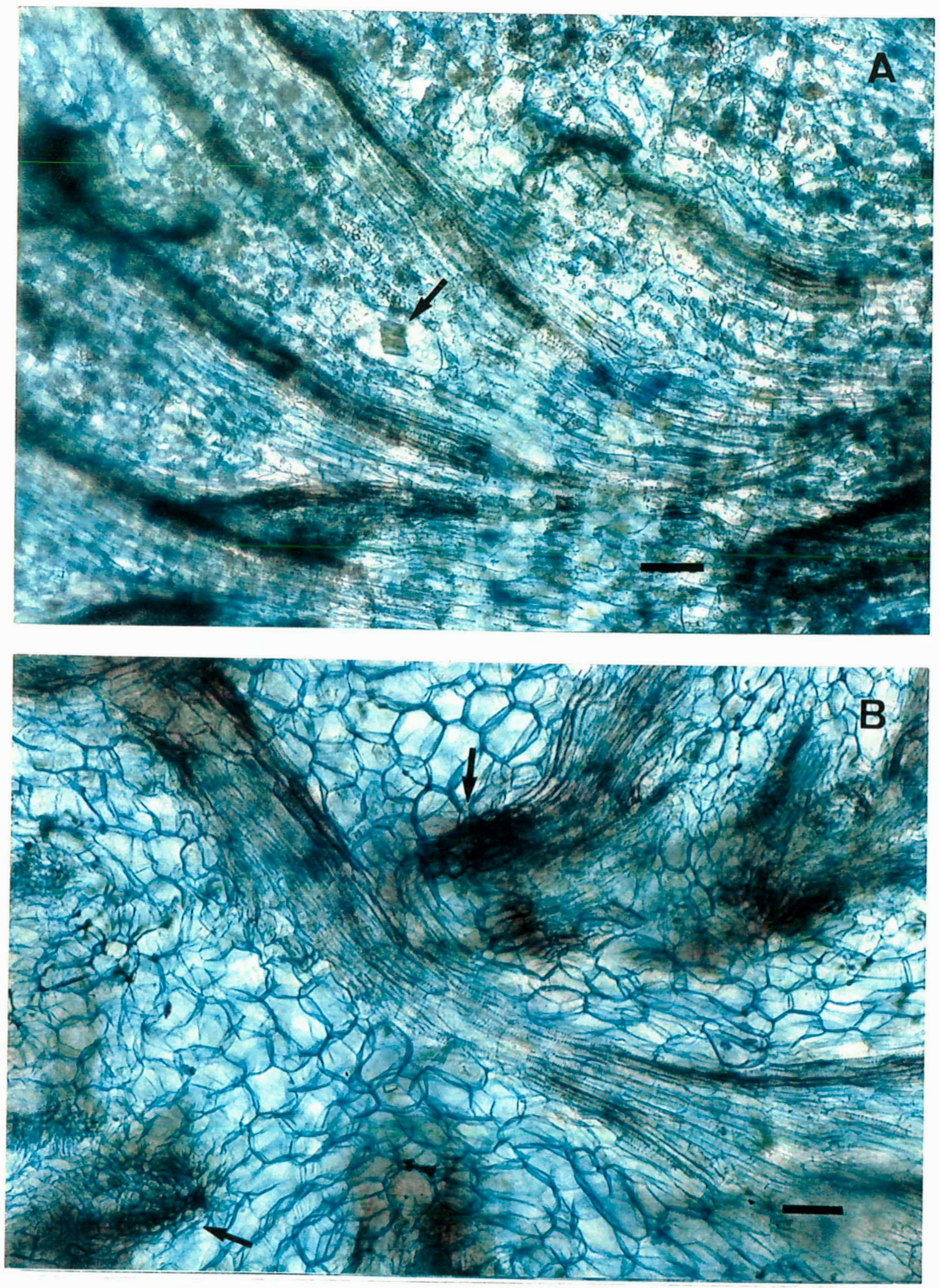

Figura 4 - Protuberâncias de explantes foliares de C. sinuosus após 2 meses de cultura em BAP a $4,4 \mu \mathrm{M}$, ANA a $0,1 \mu \mathrm{M}$.

$A$ - ráfides indicado pela seta ( barra $1 \mathrm{~cm}=100 \mu \mathrm{M}$ )

$\mathrm{B}$ - xilema indicado pela seta ( barra $1 \mathrm{~cm}=50 \mu \mathrm{M}$ ) 
Tabela 2. Efeito de diferentes combinações $\operatorname{BAP} / \mathrm{ANA}(\mu \mathrm{M})$ sobre a percentagem de regeneração e o número de brotos e plântulas por explante de folha de Cryptanthus sinuosus.

\begin{tabular}{|c|c|c|c|c|c|}
\hline \multicolumn{2}{|c|}{$\begin{array}{c}\text { Combinações } \\
\text { BAP/ANA }(\mu \mathrm{M})\end{array}$} & \multirow{2}{*}{$\begin{array}{c}\begin{array}{c}\% \text { de } \\
\text { explantes } \\
\text { responsivos }\end{array} \\
41,6\end{array}$} & \multirow{2}{*}{$\begin{array}{c}\text { Número médio de } \\
\text { brotos/explante }\end{array}$} & \multirow{2}{*}{$\begin{array}{l}\text { Número médio de } \\
\text { plântulas/explante } \\
8,1 \pm 1,6^{\mathrm{a}}\end{array}$} & \multirow{2}{*}{$\begin{array}{c}\text { \% de } \\
\text { conversão } \\
57,8\end{array}$} \\
\hline & 0,5 & & & & \\
\hline \multirow[t]{3}{*}{2,2} & 1 & 32,2 & $30,1 \pm 6,1^{b}$ & $22,3 \pm 2,7^{b}$ & 74,0 \\
\hline & 2,5 & 40,0 & $34,8 \pm 7,6^{\mathrm{c}}$ & $20,8 \pm 3,1^{b}$ & 59,7 \\
\hline & 0,5 & 52,9 & $28,5 \pm 8,8^{b}$ & $21,0 \pm 4,9^{b}$ & 73,6 \\
\hline \multirow[t]{3}{*}{4,4} & 1 & 50,0 & $26,1 \pm 7,6^{\mathrm{b}}$ & $21,0 \pm 4,7^{\mathrm{b}}$ & 80,4 \\
\hline & 2,5 & 58,3 & $36,7 \pm 6,6^{\mathrm{c}}$ & $34,4 \pm 7,8^{c}$ & 93,7 \\
\hline & 0,5 & 63,6 & $27,17 \pm 8,4^{b}$ & $17,8 \pm 4,0^{b}$ & 65,5 \\
\hline \multirow[t]{3}{*}{8,8} & 1 & 57,6 & $41,18 \pm 7,6^{d}$ & $28,0 \pm 5,1^{\mathrm{c}}$ & 67,9 \\
\hline & 2,5 & 80,3 & $41,29 \pm 9,7^{\mathrm{d}}$ & $26,1 \pm 6,7^{\mathrm{c}}$ & 63,3 \\
\hline & 0,5 & 72,7 & $32,2 \pm 4,8^{\mathrm{b}}$ & $15,5 \pm 2,9^{d}$ & 48,1 \\
\hline \multirow[t]{2}{*}{22} & 1 & 59,6 & $31,1 \pm 5,7^{\mathrm{b}}$ & $13,7 \pm 3,9^{d}$ & 44,0 \\
\hline & 2,5 & 72,2 & $29,8 \pm 6,4^{b}$ & $20,1 \pm 4,5^{\mathrm{b}}$ & 67,4 \\
\hline \multicolumn{2}{|c|}{$\mathrm{MSO}$} & 38 & $1,3 \pm 0,4^{\mathrm{f}}$ & $1 \pm 0^{f}$ & 76,9 \\
\hline
\end{tabular}

( \pm ) Desvio padrão

a-f- em cada coluna, médias seguidas da mesma letra não têm diferenças significativas o nível de $\alpha \leq 0,05$ através do teste-t- Student 


\section{REGENERAÇÃO IN VITRO A PARTIR DE EXPLANTES DE FOLHAS DE Quesnelia arvensis (VELLOZO) MEZ.}

\subsection{Introdução}

A importância da micropropagação de espécies que apresentam habitat com risco de extinção já foi abordada neste trabalho. Sob este aspecto, $Q$. arvensis, encontrada em área de restinga, se enquadra no mesmo perfil de $N$. cruenta e C. sinuosus.

A produção de mudas em larga escala pode ser colocada no mercado de plantas ornamentais e diminuir o extrativismo, além de disponibilizar material vegetal para projetos de recolocação desta espécie na natureza.

Neste trabalho, meios de cultura MS0 ou MS suplementado com reguladores de crescimento, sob a forma sólida e líquida, foram testados para o estudo da regeneração in vitro. Utilizou-se como explantes, folhas e caules com raízes. 


\subsection{Material e Médotos}

\subsubsection{Meios e condições de cultura}

$\mathrm{O}$ meio de cultura em que as sementes foram germinadas foi o de Murashige \& Skoog (MS), acrescido de 3\% de sacarose e solidificado com $0,7 \%$ de agar. $\mathrm{O} \mathrm{pH}$ foi ajustado a 5,8 antes da autoclavagem $\left(120^{\circ} \mathrm{C}\right.$ por 15 min.). Todas as culturas foram mantidas à temperatura de $28^{\circ} \mathrm{C}$ com fotoperíodo de 16:8 horas (luz:escuro). A irradiância total, proveniente de lâmpadas fluorescentes tipo luz do dia e gro-lux (3:1) foi de $10 \mathrm{Wm}^{-2}$.

Para indução de regeneração, o meio basal MS foi suplementado com combinações de BAP e ANA e utilizado sob a forma sólida e líquida.

A cultura em meio líquido foi realizada em $50 \mathrm{ml}$ de meio MS, mantido sob agitação (150 rpm), em mesa agitadora (marca Lab-Line Instruments, modelo Orbit).

\subsubsection{Cultura de explantes}

Sementes de Q.arvensis foram coletadas na restinga de Carapebus $(\mathrm{RJ})$. A descontaminação superficial foi efetuada com lavagem em água e detergente e subsequente imersão em álcool $70 \%$ por $3 \mathrm{~min}$. Em seguida, as sementes foram imersas em solução de hipoclorito de sódio a 5\% acrescida 
de tween (80) a $0,01 \%$ por 15 min., sob agitação. Ao final de três lavagens com água destilada esterelizada, as sementes foram inoculadas em meio MS0 sólido.

Após 50 dias, as plântulas obtidas foram utilizadas como doadoras de explantes (folhas e caules com raízes) Figura 5A. Os explantes foram inoculados em meio MS0 sólido ou líquido, complementados com reguladores de crescimento.

Vinte explantes de folhas e 10 de caules com raizes foram utilizadas inicialmente em cada tratamento. Procedeu-se a duas repetições dos experimentos. O meio sólido foi colocado em recepiente de vidro de $250 \mathrm{ml}$. O meio líquido foi colocado em erlemeyer de $300 \mathrm{ml}$. Em ambos usou-se a quantidade de $30 \mathrm{ml}$ de meio.

As subculturas foram realizadas a cada 4 semanas em ambos os meios. Eram considerados brotos aqueles que alcançavam $1 \mathrm{~cm}$ de comprimento, quando eram exsisados e transferidos para o meio MSO. Após 2 meses as mudas foram transplantadas para bandejas de isopor com retículos de $30,71 \mathrm{~cm}^{3}$, contendo substrato de Plantmax ${ }^{\circledR}$ e colocada sobre telado com sombreamento $50 \%$ de luz solar utilizando telado tipo Sombrite $囚$.

Explantes foliares foram cultivados na presença de BAP a 4,4 $\mu \mathrm{M}$ e 13 $\mu \mathrm{M}$ combinados com ANA a 0,5 e $1 \mu \mathrm{M}$. Explantes de caules com raizes foram avaliados na presença de MS0, BAP 4,4 e $22 \mu \mathrm{M}$. Os resultados foram expressos em número médio de brotos por explante.

Agregados de gemas originados da cultura de explantes caules com raízes em meio líquido, após dois meses (Figura 5B), foram separados e subcultivados em meio MS0 líquido (Figura 5C) no qual apresentaram intensa multiplicação. Três avaliações da massa de matéria fresca foram realizadas 
no período de 38 dias, após o qual amostras de 2,5g foram inoculadas em meio MS0 sólido. O desenvolvimento de brotos a partir destas amostras foi avaliado após 30 dias.

\subsection{Resultados e Discussão}

Um fator fundamental para a indução da regeneração in vitro, como já visto neste trabalho, é a composição em fitorreguladores do meio de cultura. Além disso, diversos tipos de explantes e fatores físicos devem ser avaliados durante o estabelecimento de protocolos para a regeneração de plantas (Yang et al., 1986).

O balanço entre auxmas e citocininas deve ser adequado à etapa específica da regeneração que se deseja induzir (Hirimburegama \& Wijesinghe, 1992). Na bibliografia consultada, é expressivo o número de autores que testaram os efeitos das combinações de auxinas e citocininas na regeneração de bromélias, conforme indica o quadro 1 .

A taxa de germinação de $Q$. arvensis em meio MS0 foi de $85 \%$. Para a indução da organogênese a partir de explantes foliares foram estudadas diferentes combinações dos fatores de crescimento ANA e BAP. Entre as combinações testadas, a que induziu uma melhor formação de brotos, em um período de 60 dias, foi ANA $0,5 \mu \mathrm{M}+$ BAP 4,4 $\mu \mathrm{M}, 11$ brotos/explante (tabela 3).

Tanto nos meios sólidos quanto em meios líquidos, as folhas iniciaram a resposta, na parte basal, após um período de 15 dias de cultivo, com a formação de protuberâncias. A ocorrência de protuberâncias em explantes 
foliares de bromélias mantidos na presença de combinações de citocininas e auxinas foi referida anteriormente, neste trabalho.

Os explantes foliares permaneceram aparentemente saudáveis nos meios sólidos. Entretanto, em meio líquido, 50\% destes explantes oxidaram após duas semanas.

A agitação promoveu maior contato do $\mathrm{O}_{2}$ com o tecido o que facilitou a necrose. Quando explantes caule+raíz foram submetidos a mesmas condições de meio e agitação a oxidação não ocorreu.

A cultura líquida para regeneração de brotos de Q.quesneliana, a partir de folhas inoculadas em meio MS acrescido de ANA e BAP, já havia sido relatada por Hosoki \& Asahira (1980), a uma taxa de 10,5 brotos/folha.

Tabela 3 - Número médio de brotos produzidos por explante foliar, em resposta a diferentes concentrações de ANA e BAP, 60 dias após o início da cultura.

( \pm ) Desvio padrão

\begin{tabular}{crr}
\hline $\begin{array}{c}\text { Combinações } \\
\text { ANA/BAP }(\boldsymbol{\mu M})\end{array}$ & Meio sólido & Meio líquido \\
\hline $0,5+4,4$ & $11,66 \pm 1,10$ & $11,25 \pm 2,49$ \\
$0,5+13$ & $8,77 \pm 1,45$ & $5,66 \pm 0,98$ \\
$1+4,4$ & $4,87 \pm 0,87$ & $3,75 \pm 1,54$ \\
$1+13$ & $7,6 \pm 1,08$ & $7,66 \pm 3,71$ \\
\hline
\end{tabular}


Explantes de caules com raízes haviam sido utilizados na micropropagação de Ananas comosus, com o objetivo de induzir estiolação, quando inoculados em meio suplementado com ANA e mantidos na ausência de luz por 40 dias (Kiss, 1995).

Os explantes de caules com raizes foram inoculados em MS0 líquido ou sólido e, após um período de 10 dias, iniciaram um processo de multibrotação. A resposta morfogênica destes explantes em meio líquido foi superior à obtida em meio sólido (Tabela 4). A utilização de BAP diminuiu a formação de brotos. A melhor média de formação de brotos (11,3 brotos por explante) para os explantes de caules com raízes foi obtida em MS0 líquido, 60 dias após a inoculação.

Tabela 4- Número médio de brotos de $Q$. arvensis originados a partir de explantes de caules com raizes após 60dias. $( \pm)$ Desvio padrão.

\begin{tabular}{|c|c|c|}
\hline De the & What butes & 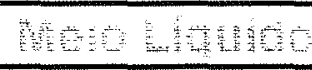 \\
\hline MSO & $1 \pm 0$ & $11,33 \pm 5,2$ \\
\hline 4,4 & $1 \pm 0$ & $6,00 \pm 0,4$ \\
\hline 22 & $2 \pm 0$ & $1,00 \pm 0$ \\
\hline
\end{tabular}


Além disso, após um período de 30 dias, ocorreu a formação de agregados de gemas que, ao serem subcultivados em meio líquido, demonstraram uma ótima capacidade de multiplicação, avaliada pelo aumento da massa de matéria fresca. Estes agregados aumentaram 5 vezes sua massa de matéria fresca em meio MSO líquido sob agitação de $150 \mathrm{rpm}$. como pode ser observada na figura 6. Ao contrário, em meios suplementados com BAP, intensa oxidação do material foi observada, após um período de 20 dias.

Após a reinoculação dos agregados em meio MS0 sólido, ocorreu o desenvolvimento de um número médio de 185 brotos por grama de material agregado, após 30 dias. Portanto, este sistema apresentou um alto o potencial de produção. Foram obtidos cerca de 8.300 brotos por semente, 5 a 6 meses após a semeadura, dispensando a utilização de reguladores de crescimento.

Devido a esta alta eficiência de regeneração, este sistema é uma alternativa que deve ser avaliada para outras espécies da família. 

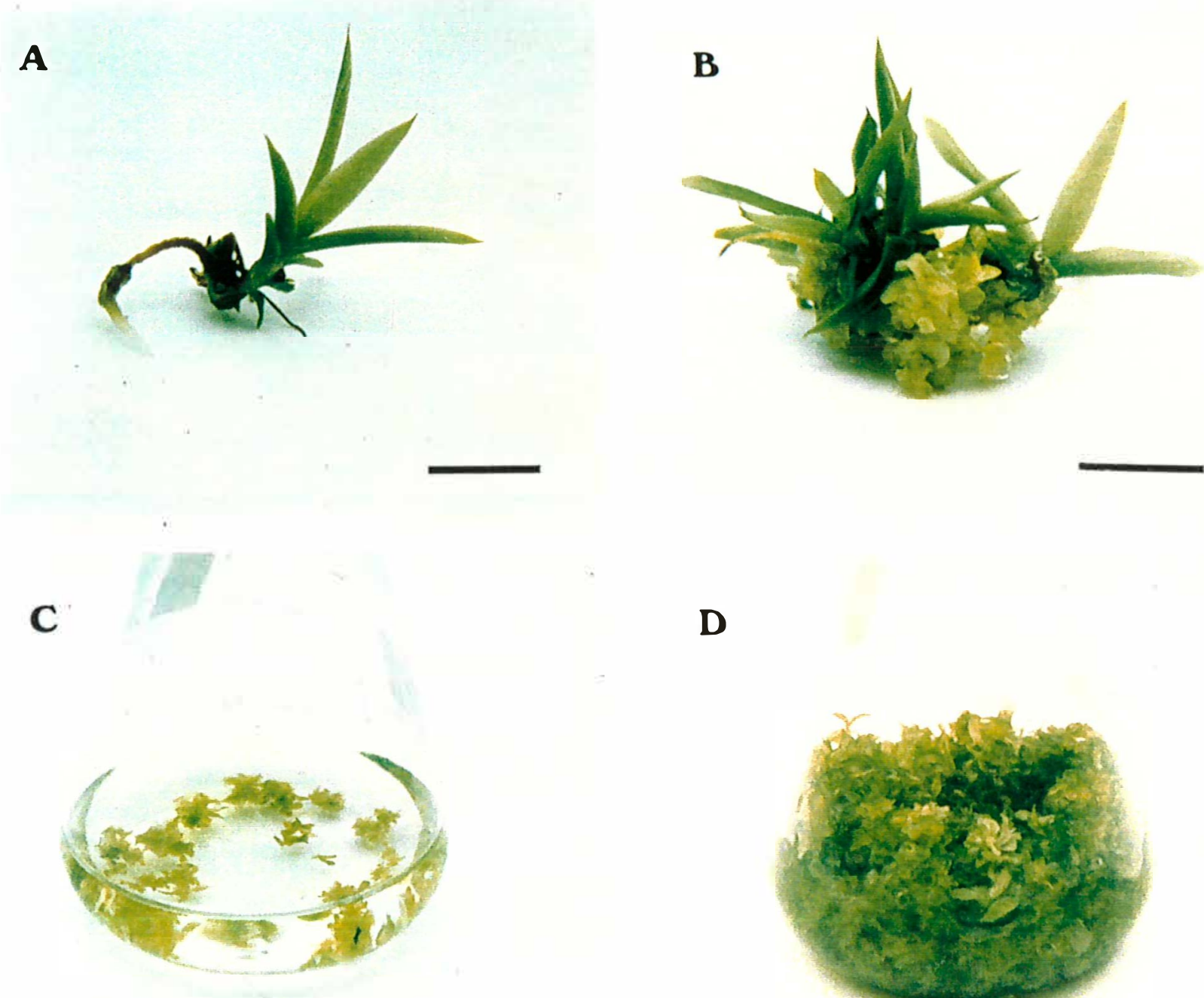

\section{D}

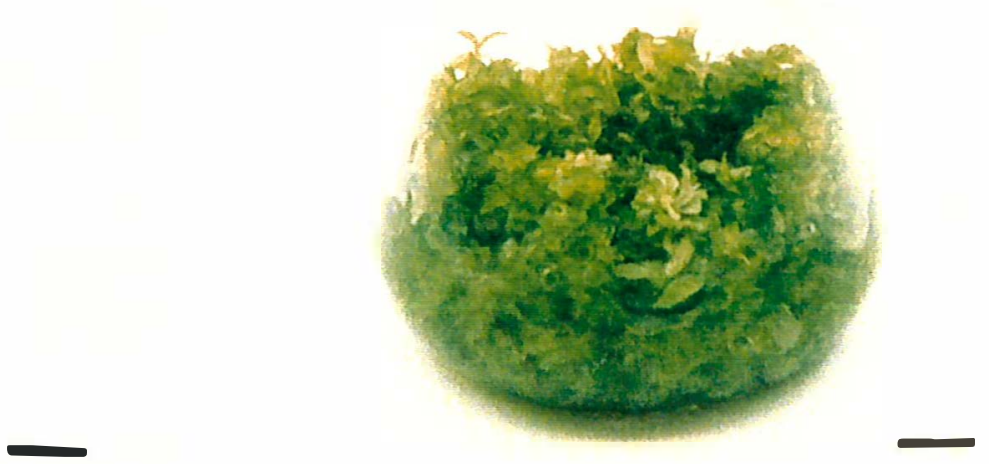

Figura 5 - Regeneração in vitro de (Q. arvensis.

A-Plântula 50 dias após a germinação em meio MSO líquido

B-Aglomeradas de gemas formadas a partir de explante caules com raízes após 2 meses em meio MSO líquido.

C-Aglomerado de gemas no início da subcultura.

D-Aglomerados de gemas após 50 dias de cultura. 


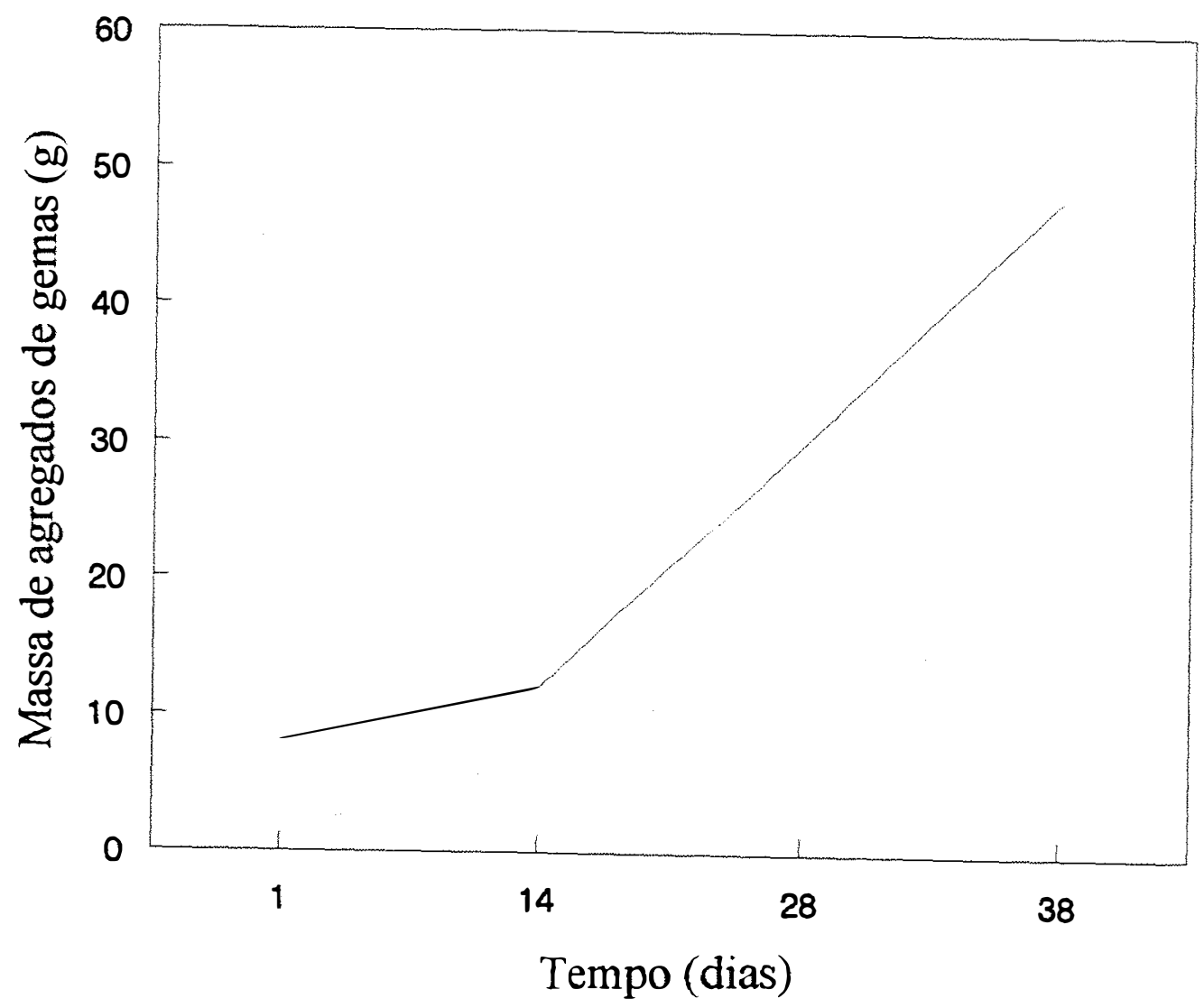

Figura 6. Variação da massa de matéria fresca dos agregados de gemas. Os agregados foram produzidos a partir de explantes de caules com raízes cultivados em meio MS0 líquido e subcultivados no mesmo meio. As culturas foram mantida sob agitação, a 150 rpm. 


\section{ACLIMATIZAÇÃO DE PLÂNTULAS DE Cryptanthus sinuosus, Neoregelia cruenta e Quesnelia arvensis}

\subsection{Introdução}

A aclimatização é apontada como uma das fases mais críticas do processo de micropropagação de plantas. Porém, ao contrário do que seria esperado, de uma forma geral, os trabalhos de micropropagação não relatam os procedimentos, dificuldades e soluções para o processo de aclimatização.

Cozai \& Kitaya (1995) analisaram os componentes do ambiente in vitro e listaram os seguintes fatores variáveis, relativos à parte aérea de plantas obtidas por micropropagação: baixa taxa fotossintética líquida em conseqüência do baixo fluxo fotônico, baixa taxa de transpiração, baixo fluxo de radiação térmica líquida e elevada taxa respiratória. Quanto à parte radicular, foram citadas baixa taxa de absorção de água, baixa taxa de absorção de íons minerais e baixa absorção de açúcar.

Baker (1974), Sutter \& Langhans (1979) e Grout (1975) ressaltam que é reduzida ou até ausente a quantidade de cera epicuticular das folhas in vitro, quando comparadas com folhas de plantas em casa de vegetação ou no campo.

Quanto aos estômatos, as opiniões são divergentes, dependendo do tipo de vegetal analisado. Brainerd e Fuchigami (1981) e Leshem 
(1983), trabalhando com amexeiras e cravo, respectivamente, observavam que estômatos de folhas in vitro apresentaram-se em número reduzido ou ineficientes quanto ao mecanismo de abertura e fechamento. Por outro lado, Wetzstein \& Sommer (1982) trabalhando com eucalipto encontraram maior densidade estomatal em folhas de plântulas in vitro do que em folhas aclimatizadas. A pequena ordenação da camada paliçádica também é característica de folhas desenvolvidas in vitro (Brainerd e Fuchigami 1981, Donnelly et al, 1985 e Donnelly \& Vidaver (1984) classificam estes traços anatômicos superficiais induzidos pelo ambiente de cultura como efeitos epigenéticos.

A umidade relativa, a temperatura constante do ar, a concentração de $\mathrm{CO}_{2}$ baixa na luminosidade e elevada no escuro, bem como a alta concentração de etileno são fatores constantes que afetam a parte aérea. Por outro lado, a baixa concentração de oxigênio dissolvido, a elevada concentração de compostos fenólicos e substâncias tóxicas, a elevada concentração de açúcar e íons minerais, a baixa densidade de microrganismos e as altas concentrações de reguladores de crescimento interagem com as raízes (Cozai \& Kitaya, 1995).

Estes fatores tendem a ser alterados, quando a planta é retirada destas condições e transferida para outro local onde será submetida a um período de aclimattização. A dificuldade em controlar estes fatores fica evidente quando, autores como Ziv citado por Campostrini e Otoni (1996) afirmam que, em se tratando de micropropagação em escala comercial, nenhuma tecnologia convencional de aclimatização resolve eficientemente o problema de mudança das condições in vitro para ex vitro. 
Campostrini \& Otoni (1996) definem a proposta tradicional de aclimatização ex vitro das plantas micropropagadas como "um progressivo aumento da irradiância sob alta umidade relativa do ambiente, com gradativa redução da mesma até o final da fase de adaptação’.

Durante a aclimatização em casa de vegetação, o controle de luz pode ser efetuado com a utilização de sombrite. A umidade é conservada elevada por cobertura plástica da plântula, irrigações ou nebulizações. A nutrição pode ser conduzida com auxílio de solução nutritiva balanceada, aliada ao aumento das condições autotróficas da planta quando a folha eleva a sua capacidade fotossintética (Desjardins et al., 1987; Grout \& Aston, 1977 e Zimmerman, 1988)

Alguns equipamentos que visam aumentar a taxa de $\mathrm{CO}_{2}$ em câmaras com luz e umidade controladas, como a elaborada por Laforge et al (1990), são tentativas de acelerar o desenvolvimento da competência fotossintética. Este estímulo durante a fase in vitro melhora,o estabelecimento da planta ex vitro e se constitui o último avanço do pesquisa sobre este tema, segundo Deng \& Donnelly (1993), Lees et al, (1991) e Desjardins et al, (1987).

Uma condição importante para o sucesso da formação de mudas, na fase de aclimatização ex vitro, é o tipo de substrato utilizado devido aos efeitos propiciados na translocação de água no sistema solo-planta-atmosfera (Orlander \& Due, 1986) e à facilidade para o estabelecimento da arquitetura do sistema radicular (Spurr \& Barnes, 1973).

Segundo Coutinho \& Carvalho (1993), o melhor substrato é aquele que, além de rico em nutrientes, possui uma composição química e física 
uniforme, baixa densidade, elevada capacidade de troca catiônica e boa coesão entre as partículas, com eficiente capacidade de retenção de água, aeração e drenagem. Outras qualidades como isenção de pragas, microorganismos patogênicos e sementes de plantas daninhas são também condições básicas para a otimização do sistema.

A procura de substratos alternativos para aclimatização, desenvolvimento de mudas ou plantas adultas tem sido preocupação de pesquisadores e colecionadores que se opõe ao uso do xaxim. Este tipo de substrato fibroso deve ser abandonado, devido ao elevado risco de extinção causado pela descontrolada extração por parte de produtores de materiais de uso horticultural. Zomig (1996), ao relatar as condições da aclimatização de plântulas micropropagadas indica que necessitam de substrato leve, aerado, balanceado em nutrientes e com pH entre 5 e 5,5. Kämpf (1995) obteve sucesso no crescimento de mudas, na fase final de juvenilidade em vasos contendo argila expandida conhecida como cinasita, ajustando o $\mathrm{pH}$, que pode chegar a 7,5, para valores em torno de 5 a 5,5. Outras iniciativas como adubação mineral por via radicular ou foliar dependem da espécie. A reserva de água em pratos na base do vaso é também um fator importante. Sementes de diversos gêneros de bromélias provenientes de bagas ou cápsulas formam plântulas em uma camada de $4 \mathrm{~cm}$ de matéria orgânica de origem vegetal (Menescal, 1994).

O cultivo de plantas do gênero Cryptanthus, que apresenta raízes não muito profundas, é feito em diferentes substratos desde que não seja dispensado o uso de matéria orgânica. A adubação com liberação lenta de 
nutrientes como Osmocote® (14-14-14) ou adubo na forma líquida também são recomendados por Cândido (1996).

$\mathrm{Na}$ pesquisa bibliográfica realizada não foram encontrados trabalhos sobre aclimatação de plântulas de $N$. cruenta ou de $Q$. arvensis. 


\subsection{Material e Métodos}

\subsubsection{Material Botânico}

Os procedimentos da micropropagação de bromélias aqui estudados levaram à produção de numerosos brotos. Estes foram considerados plântulas quando possuíam altura superior $1 \mathrm{~cm}$ e foram transferidas para meio MSO onde enraizaram no período de 2 meses, só então sendo transferidos para os substratos de aclimatação.

As plântulas de Cryptanthus sinuosus utilizadas foram obtidas em meio contendo $4,4 \mu \mathrm{M}$ BAP e $2,5 \mu \mathrm{M}$ ANA, a partir de explantes de folhas provenientes de brotos mantidos in vitro.

O material de $N$. cruenta foi originado de brotos que se formaram em meio MS complementado com 4,4 $\mu \mathrm{M}$ BAPe 2,5 $\mu \mathrm{M}$ ANA, derivados de folhas de plântulas obtidas a partir da germinação in vitro de sementes.

As plântulas de $Q$. arvensis foram obtidas a partir da cultura em MSO líquido de explantes de caules com raízes. 


\subsubsection{Condução do experimento}

As plântulas foram separadas em dois grupos. O grupo $\mathrm{A}$ foi composto de plântulas com massa de matéria fresca entre 0,5 e $0,33 \mathrm{~g}$ e o grupo B foi formado por plântulas com 0,12 a $0,95 \mathrm{~g}$.

$\mathrm{Na}$ análise de $C$. sinuosus e $N$. cruenta, 50 plântulas foram utilizadas em cada grupo, por experimento. Trinta plântulas de $Q$. arvensis foram observadas por grupo. As plântulas foram transferidas para bandejas de isopor com retículos de $30,71 \mathrm{~cm}^{3}$ que continham $16 \mathrm{~g}$ do substrado I ou $34 \mathrm{~g}$ do substrato II. Os experimentos foram repetidos duas vezes, com duração de 120 dias.

O substrato I foi do tipo Plantmax, produzido pela Eucatex, à base de vermiculita e matéria orgânica de baixa densidade e $\mathrm{pH}$ 6,5. Para o substrato II, foi utilizado o Plantmax misturado com areia na proporção 1:1 com $\mathrm{pH}$ 6,3. A areia fina foi obtida na reserva de Maçambaba em Saquarema, mesmo local de onde foram obtidas as sementes de $N$. cruenta utilizadas neste trabalho.

A redução de $50 \%$ da luz solar foi providenciada com o uso de Sombrite ${ }^{\circledR}$, colocado a $95 \mathrm{~cm}$ acima das bandejas. Para a adubação, foram aplicados $10 \mathrm{ml}$ da solução de Hoagland e Amon descrita por Gallo (1980), citada no quadro 2 , por planta, sobre as folhas, a intervalos de 15 dias. A irrigação foi realizada com colocação de $50 \mathrm{ml}$ de água, diariamente no $1^{\circ}$ mês e de 3 em 3 dias no período restante de experimento. Não foram 
do substrato aderido a raiz. Após a lavagem, as plântulas foram colocadas entre folhas de jornal, para secagem, por 5 minutos, antes da pesagem.

\subsubsection{Análise histológica}

Para analisar alguns aspectos histológicos de folhas de Cryptanthus sinuosus de plântulas que permaneceram nas condições in vitro e estabelecer comparações com folhas de plântulas da mesma idade após 120 dias nas condições ex vitro já descritas, foram estudados cortes transversais da folha e epiderme da folha.

As folhas recém coletadas foram submetidas a secções, transversais (ST), na região do seu terço médio, com auxílio de um micrótomo marca Ranvier com espessura em torno de 8 a $10 \mu \mathrm{M}$.

A coloração foi feita com solução de safrablau conforme Bukatsch(1972).

As epidermes abaxial e adaxial foram dissociadas manualmente, lavadas com água destilada e coradas com safranina. Os cortes foram montados em lâminas com glicerina a $50 \%$ e lutadas com esmalte incolor. As fotomicrografias foram obtidas com o emprego de estereomicroscópio Olympus.

A vista frontal da epiderme foi analisada para a determinação do número de estômatos por $\mathrm{mm}^{2}$ de folha. $\mathrm{O}$ cálculo foi feito a partir da média aritmética de 10 campos com área de $4 \mathrm{~mm}^{2}$. Os cortes de tecido in vitro apresentaram 12 estômatos por $\mathrm{mm}^{2}$. Os de tecido ex vitro, 16 estômatos por $\mathrm{mm}^{2}$. Os estômatos eram do tipo paracíticos. 


\subsection{Resultados e Discussão}

\subsubsection{Variação da massa de matéria fresca}

$\mathrm{Na}$ tabela 5 pode ser observada a variação da massa de matéria fresca em plântulas 120 dias após serem transplantadas para os substratos I e II. O aumento da massa de matéria fresca variou de 81,8 a $90,6 \%$ entre plântulas de $C$. sinuosus e $N$. cruenta e de 81,18 a 93,34\% em $Q$. arvensis, portanto diferenças pouco significativas. A bibliografia consultada não indicou valores para fins comparativos com os dados aqui conseguidos.

Zornig (1996) recomenda o pH 5 a 5,5 para a aclimatação de plântulas de bromélias. Ao longo do experimento, houve uma variação do $\mathrm{pH}$ no substrato I de 6,5 para 5,8 e no substrato II de 6,5 para 6,0 . No substrato II, com pH mais alcalino, os ganhos de massa de matéria fresca sempre foram menores em termos percentuais, porém estas diferenças não foram significativas. Assim, a diminuição de $\mathrm{pH}$ nas condições em que o experimento foi realizado não impediu o desenvolvimento das mudas, provavelmente, por estas plantas terem, nesta fase de desenvolvimento, necessidade de um $\mathrm{pH}$ menor do que 6.

Outro fator de importância é a capacidade de retenção de água e nutrientes pelo substrato e posterior disponibilidade para a raiz. Como pode 
ser observado na figura 10, o comprimento das raízes de C.sinuosus é maior no substrato II, onde a retenção de água e nutrientes na fração areia é pequena. Apesar de não possuir raízes bem desenvolvidas, em ambos os substratos as plantas de $N$. cruenta apresentaram partes aéreas maiores em substrato I, que podem indicar uma melhor nutrição mineral. Plantas de $Q$. arvensis não foram cultivadas em substrato II, porém o que pode ser observado é que o substrato I revelou ser muito bom para os dois grupos de plantas testados.

Novas análises dispondo de um intervalo maior para $o$ desenvolvimento das mudas se fazem necessárias, para confirmar se o substrato I, mais orgânico, é efetivamente mais eficiente quando comparado com outros

Com os dados colhidos aqui, conclui-se que estas bromélias provenientes da cultura in vitro são plantas que se adaptam com facilidade a variações de umidade e luminosidade ex vitro.

\subsubsection{Análise histológica}

Alguns aspectos histológicos das folhas de Cryptanthus sinuosus de plântulas que permaneceram nas condições in vitro foram comparados com os de folhas de plântulas de mesma idade, provenientes de condições $e x$ vitro, estão expostas nas figuras 7,8 e 9 .

$\mathrm{Na}$ Figura 7A, a secção transversal do terço médio da folha de plântula de Cryptanthus sinuosus in vitro mostra o tecido paliçádico com 
células pequenas e desordenadas. As duas epidermes (adaxial e abaxial) não apresentaram reação para o corante safranina (vermelho), o que indica a presença de pouca quantidade de substâncias graxas do tipo suberina e cutina. Isto também é indício da pouca lignificação. As epidermes são formadas por uma só camada de células ( Figura 7B) (Souza \& Neves, 1996).

A secção transversal do terço médio da folha de plântula de Cryptanthus sinuosus, após 120 dias em condição de aclimatação, mostra um ordenamento nas células de tecido paliçádico (Figura 8).

Tanto a epiderme adaxial como a abaxial possuem substância graxas que possibilitaram a reação com a safranina e apresentam uma camada dupla células no tecido epidérmico adaxial (Figura 9).

Os estômatos distribuem-se por toda a fase abaxial numa densidade aproximada de 12 por $\mathrm{mm}^{2}$ para o tecido in vitro e 16 por $\mathrm{mm}^{2}$ para o tecido ex vitro (Figura 9). Os estômatos eram do tipo paracítico segunda a terminologia Van Cothem (1973).

Não foram visualizados estômatos na face adaxial. As observações comparativas das Figuras 7,8 e 9 corroboram os relatos de outros autores sobre as modificações histológicas que o meio in vitro e ex vitro induzem nos tecidos das folhas de diferentes espécies (Brainerd et al., 1981; Donnelly \& Vidaver, 1984; Albarello, 1995).

As alterações histológicas demonstradas podem explicar porque estas plantas se adaptam com facilidade a variações de umidade e luminosidade dispensando procedimentos convencionais para aclimatização. 


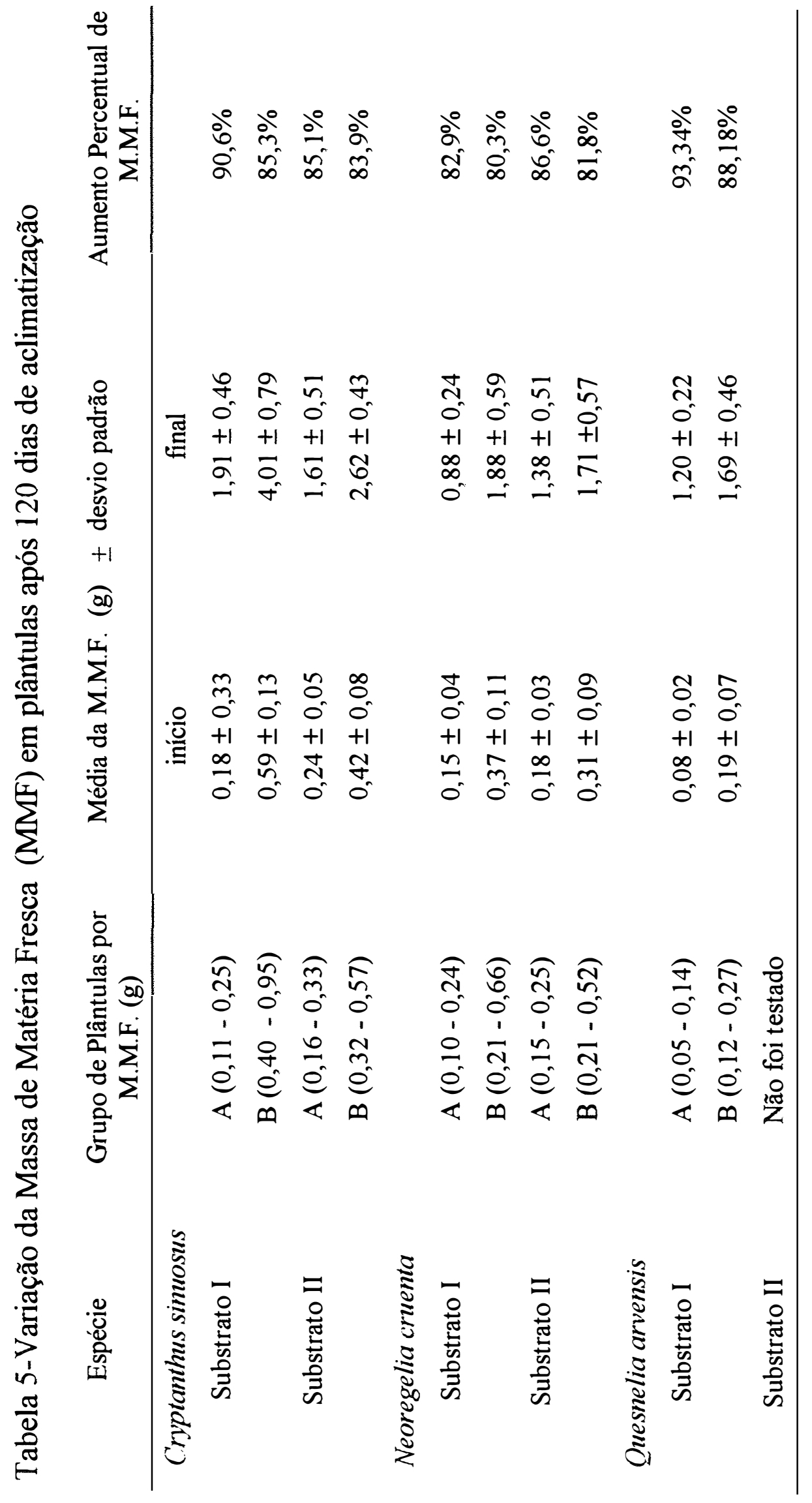



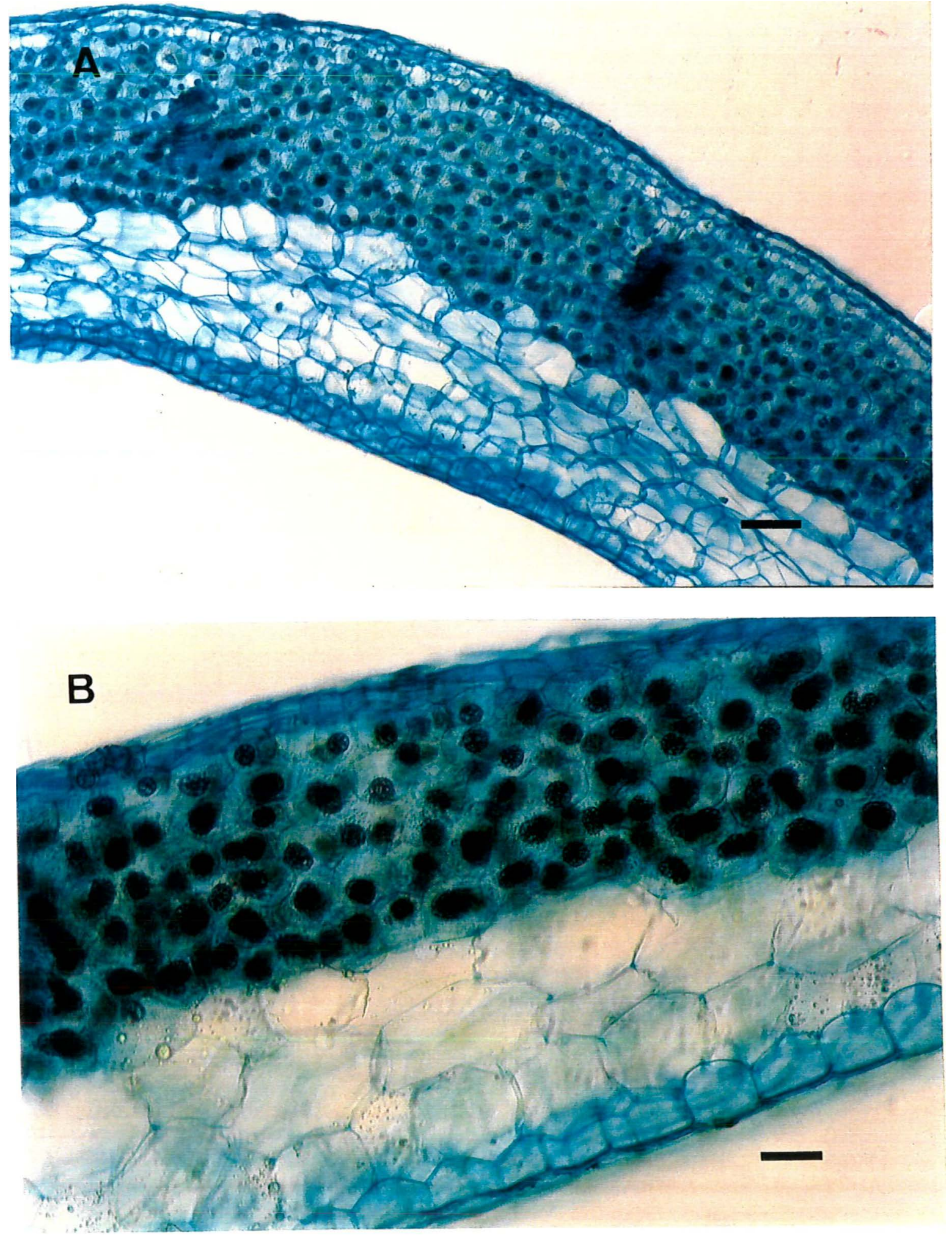

Figura 7 - Secção transversal de lâmina foliar C. sinuosus mantida in vitro por 120 dias.Em A $1 \mathrm{~cm}$ equivale a $100 \mu \mathrm{m}$ e em B $1 \mathrm{~cm}$ equivale a $50 \mu \mathrm{m}$ 

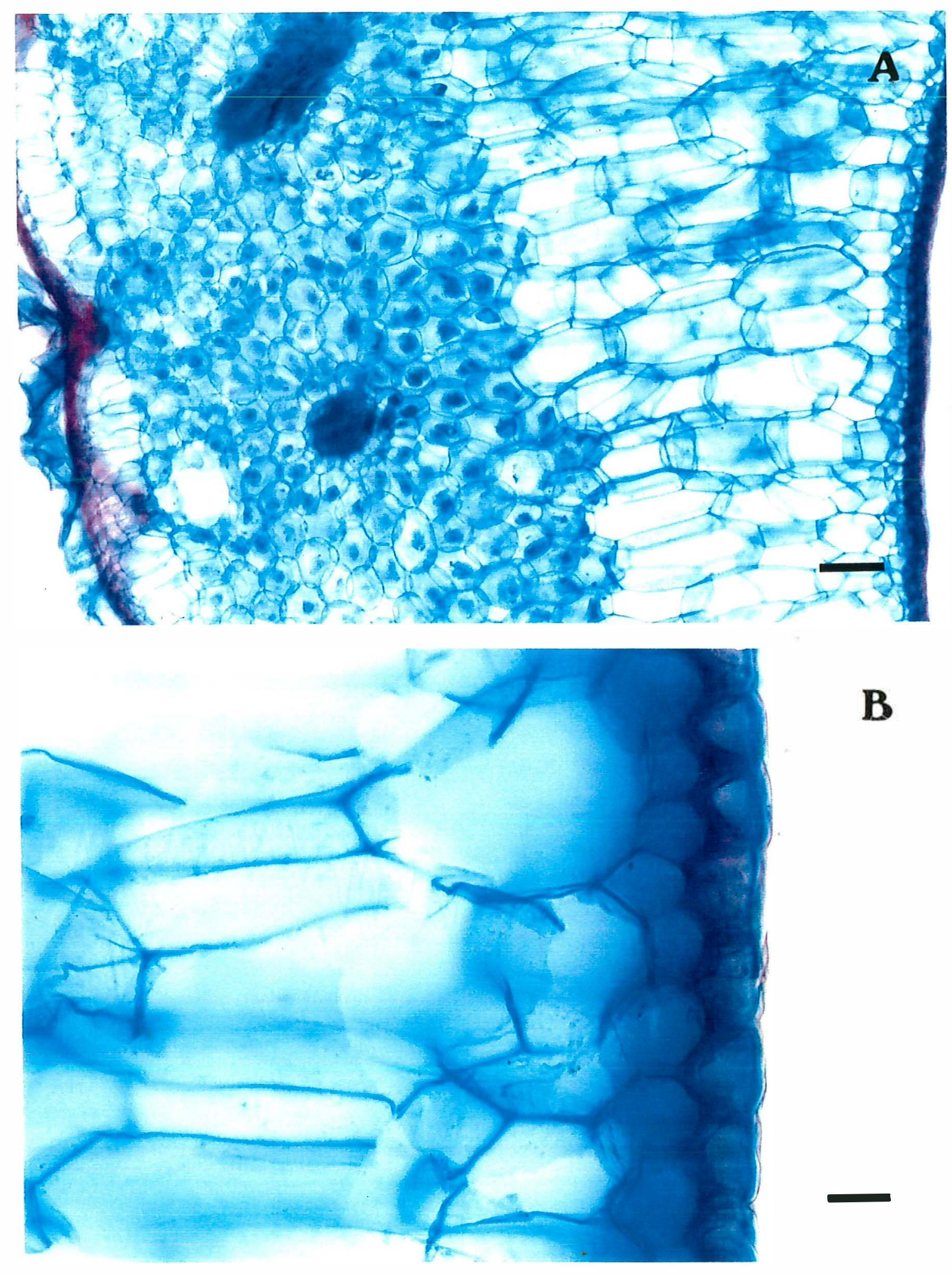

Figura 8 - Seç̧ão transversal de lâmina foliar de plântula C.sinuosus mantida ex vitro por 120 dias. Em A $1 \mathrm{~cm}$ equivale a $100 \mu \mathrm{m}$ e em B $1 \mathrm{~cm}$ equivale a $25 \mu \mathrm{m}$. 

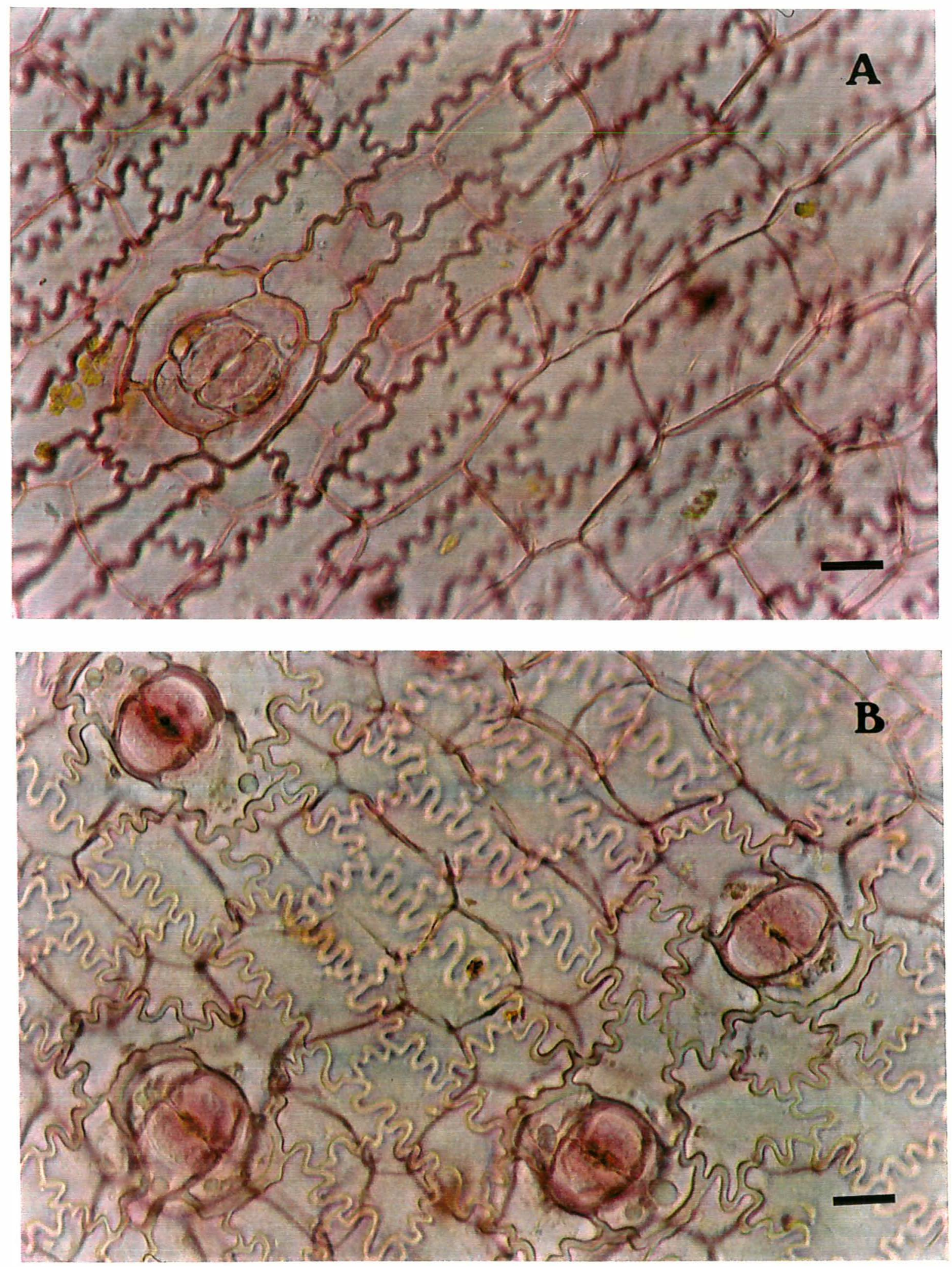

Figura 9 - Epiderme abaxial de lâmina foliar de plântula - C. sinuosus. Plântulas mantidas por 120 dias.

A - plântula in vitro

B - plântula ex vitro

Em A e em B $1 \mathrm{~cm}$ equivale a $25 \mu \mathrm{m}$ 


\section{A}
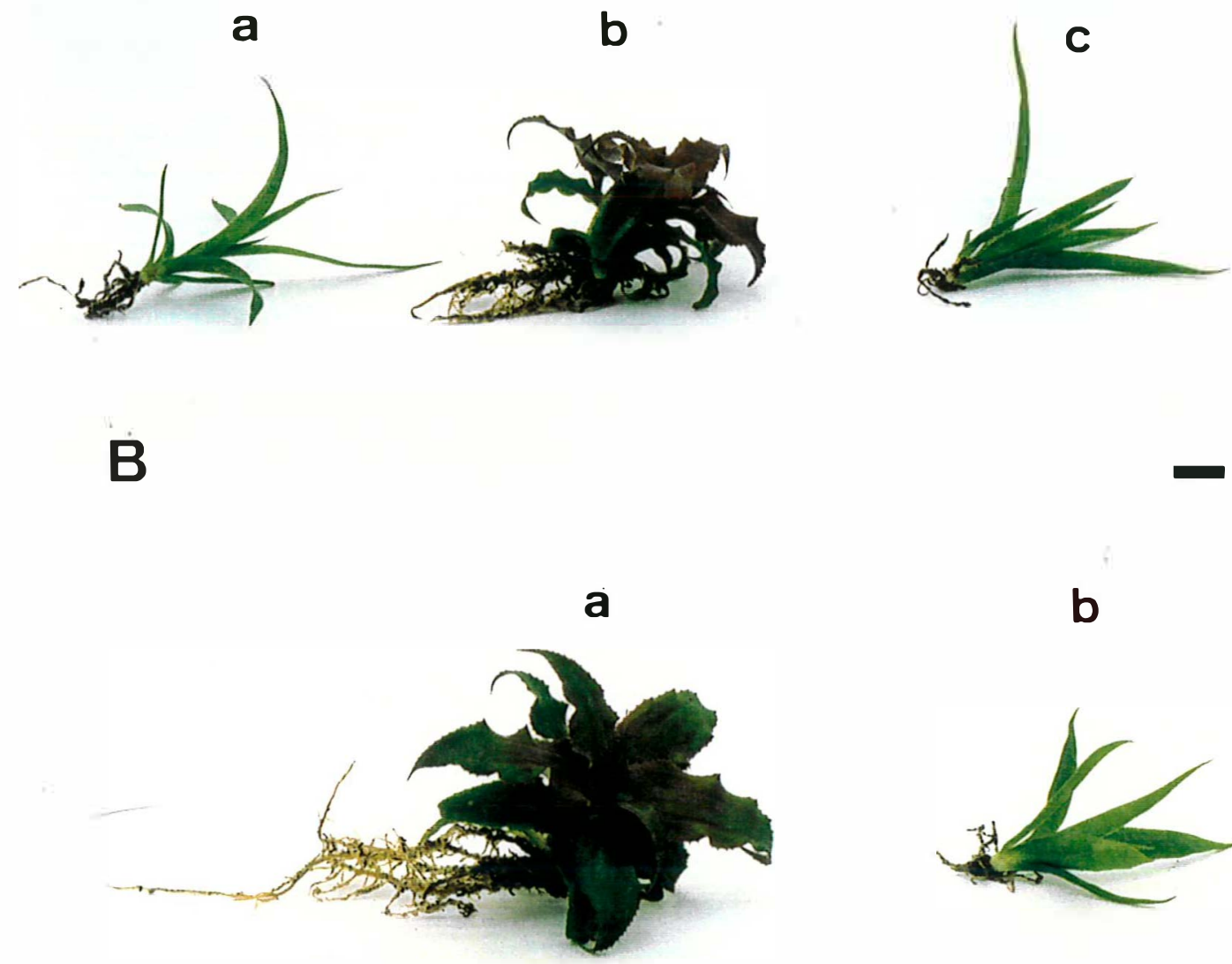

b

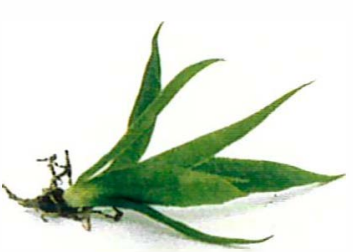

Figura 10 - Mudas de $N$. cruenta, C. sinuosus e Q. arvensis após 120 dias nas condições ex vitro.

$$
\text { A- Em substrato I }
$$

$$
\begin{aligned}
& \text { a- } Q . \text { arvensis } \\
& \text { b- C. sinuosus } \\
& \text { c- N. cruenta }
\end{aligned}
$$

B- Em substrato II a- C. sinuosus

b- N. cruenta

Em A e em B barra equivale a $1 \mathrm{~cm}$. 


\section{A}
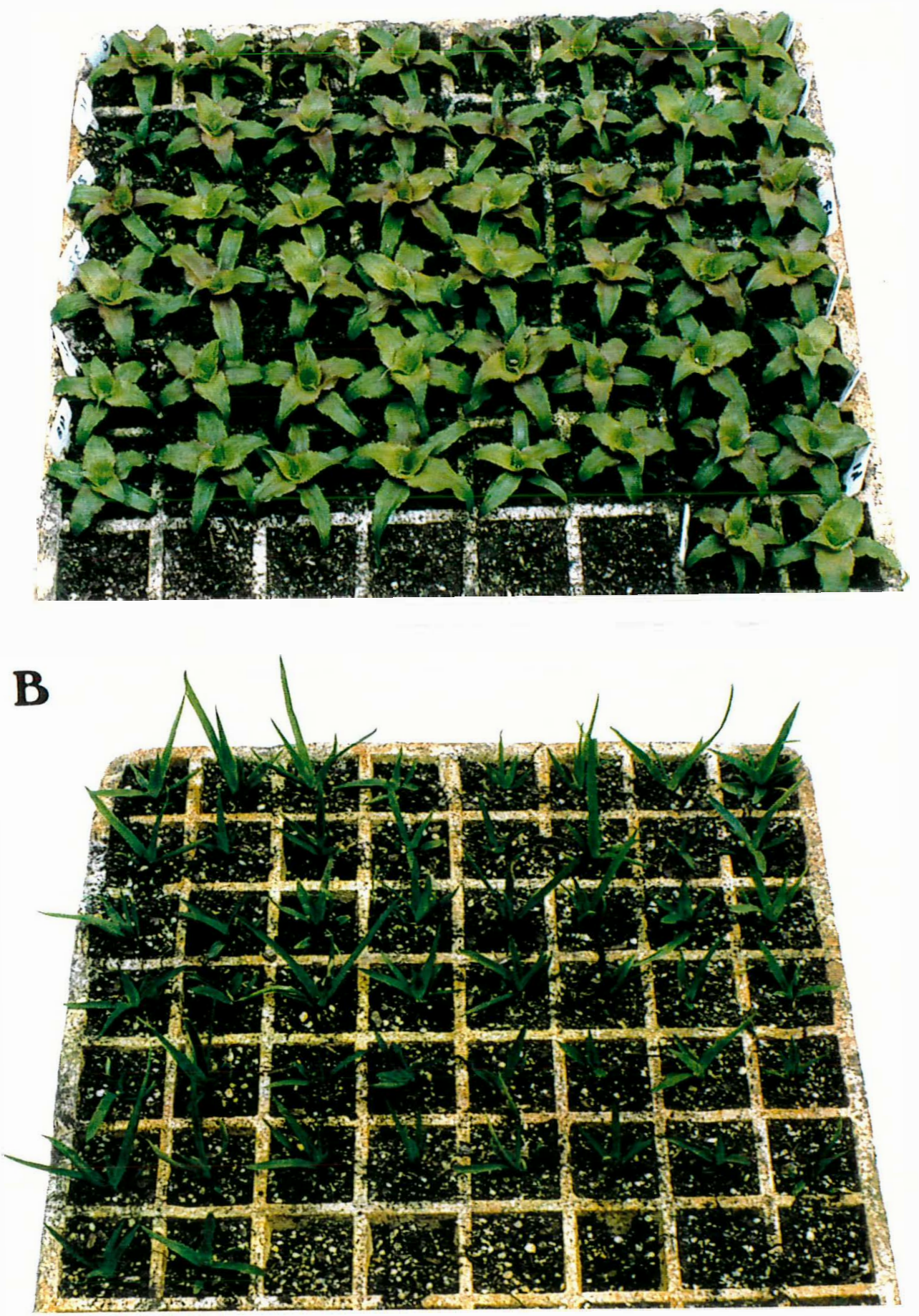

Figura 11 - Plantas em substrato Plantmax após 120 dias na condição ex vitro.

A- Cryptanthus sinuosus; B- Neoregelia cruenta. 


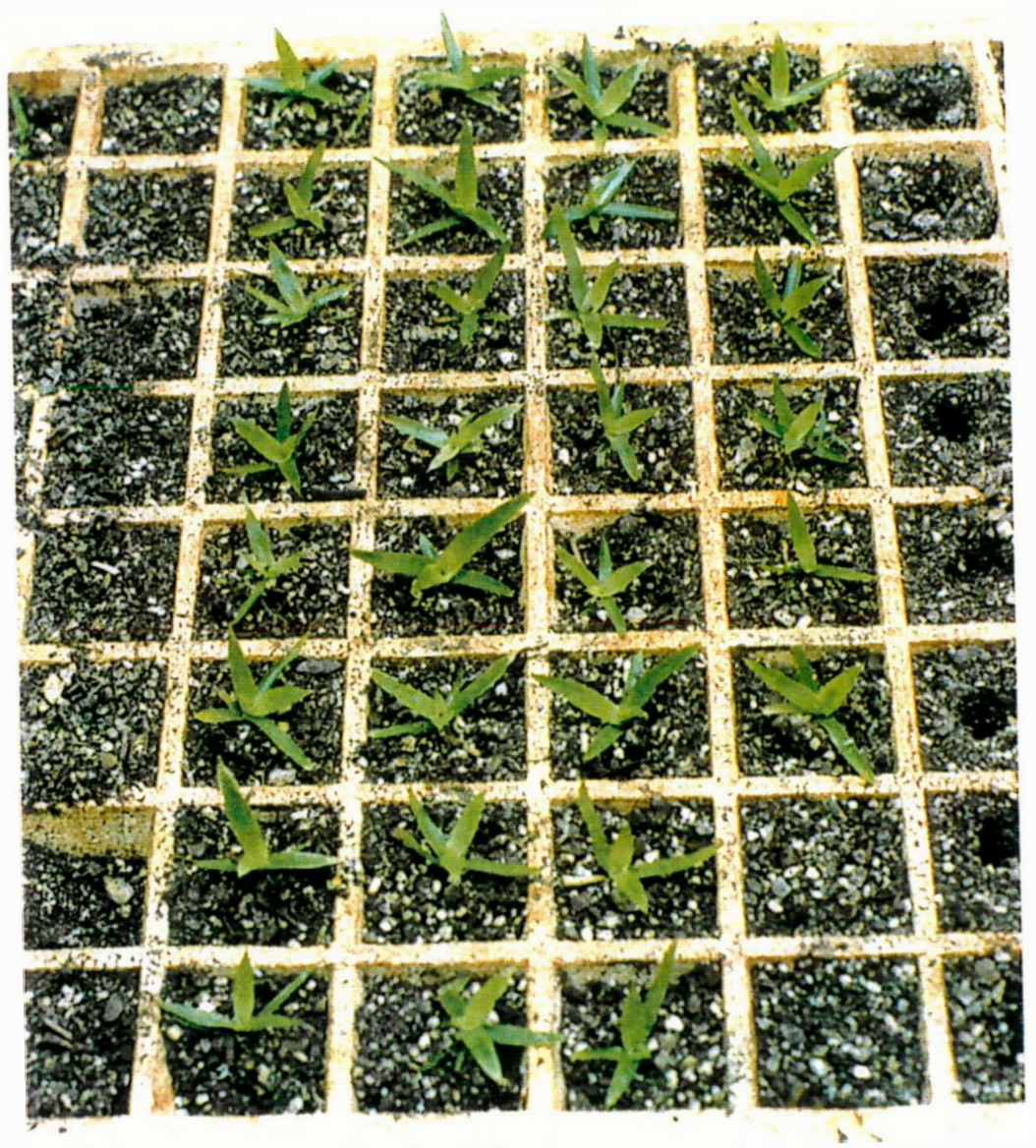

Figura 12 - Plantas de Quesnelia arvensis em substrato Plantmax após 120 dias na condição ex vitro. 
Quadro 2. Composição da Solução nutritiva de Hoagland e Amon Citado por Gallo (1980).

\begin{tabular}{lcc}
\hline Estoques & ml de solução estoque por \\
& $1 \mathrm{M}$ & 1 \\
$\mathrm{NH}_{4} \mathrm{H}_{2} \mathrm{PO}_{4}$ & $1 \mathrm{M}$ & 2 \\
$\mathrm{MgSO}_{4}$ & $1 \mathrm{M}$ & 6 \\
$\mathrm{Ca}\left(\mathrm{NO}_{3}\right)_{2}$ & $1 \mathrm{M}$ & 4 \\
$\mathrm{KNO}_{3}$ & & 1 \\
Micronutrientes (1) & & 1 \\
Fe EDTA (2) & & \\
\hline
\end{tabular}

(1) Micronutrientes (g/L)

$\begin{array}{ll}\mathrm{H}_{3} \mathrm{BO}_{3} & -2,86 \\ \mathrm{MnCl}_{2} \cdot 4 \mathrm{H}_{2} \mathrm{O} & -1,81 \\ \mathrm{CuSO}_{4} \cdot 5 \mathrm{H}_{2} \mathrm{O} & -0,08 \\ \mathrm{ZnSO}_{4} \cdot 7 \mathrm{H} 2 \mathrm{O} & -0,022 \\ \mathrm{H}_{2} \mathrm{MaO}_{4} & -0,02\end{array}$

(2) Fe EDTA - Complexo Ferro- EDTA dissódico (Etileno diamino tetra-acetato de sódio) $24,9 \mathrm{~g} / \mathrm{L}$ de $\mathrm{Fe} . \mathrm{SO}_{4} 7 \mathrm{H}_{2} \mathrm{O}$

$33,2 \mathrm{~g} / \mathrm{L}$ de ETDA dissódica 


\section{CONCLUSÕES}

As espécies de bromélias estudadas neste trabalho apresentaram regeneração in vitro eficiente, nas condições avaliadas. As estratégias adotadas foram baseadas na utilização de sementes ou estolões. Em comparação com as metodologias de cultura de meristemas, estas abordagens têm a vantagem de manter a integridade da planta doadora.

Neoregelia cruenta apresentou a taxa de regeneração mais elevada (64\%) a partir de explantes foliares excisados de plântulas de sete semanas, obtidas da germinação in vitro de sementes, e cultivados na presença de BAP a $22 \mu \mathrm{M}$ associado a ANA na concentração de $2,5 \mu \mathrm{M}$. A conversão em plantas foi mais eficiente a partir dos brotos formados em resposta à combinação BAP/ANA nas concentrações de 4,4 e 2,5 $\mu \mathrm{M}$, respectivamente.

Explantes foliares de Cryptanthus sinuosus excisados de brotos desenvolvidos a partir de estolões, quando cultivados na presença de BAP 
como único regulador de crescimento ou associado a ANA, apresentaram respostas com alta eficiência. As taxas mais elevadas de produção de brotos por explante foram obtidas na presença de BAP a $22 \mu \mathrm{M}$ e da combinação BAP a $8,8 \mu \mathrm{M}$ e ANA a $2,5 \mu \mathrm{M}$. Em explantes cultivados na presença de diferentes concentrações de TDZ, embora fossem observadas altas taxas de indução de gemas, a conversão a brotos foi muito limitada. Explantes de caule apresentaram taxas de regeneração muito reduzidas, nos meios testados.

Explantes de caules com raizes de Quesnelia arvensis, excisados de plântulas obtidas de sementes germinadas in vitro apresentaram as mais altas taxas de regeneração quando cultivados em meio MS líquido, sem a presença de reguladores de crescimento. Além do desenvolvimento de brotos, estes explantes formaram agregados de gemas que apresentaram intensa multiplicação em sucessivas sub-culturas para o mesmo meio.

Após transferência para solo, as plântulas obtidas das três espécies foram mantidas em casa de vegetação, com redução de $50 \%$ da luz solar, sem necessidade de nenhum outro procedimento tradicional visando a aclimatização. As mudas obtidas foram fenotipicamente normais. 
Os protocolos aqui desenvolvidos poderão ser utilizados como base para estabelecimento de metodologias de conservação in vitro, podendo também ser aplicados em programas de reintrodução e produção massal de mudas para comercialização. 


\section{REFERÊNCIAS BIBLIOGRÁFICAS}

ALBARELlO, N. Anatomia foliar de Rollinia mucosa (Jacq.)Baill. Annonaceae-Aspectos de Desenvolvimento 'in vitro' e 'ex vitro'. Rio de Janeiro,1995.132p.Dissertação(MS)-Universidade Federal do Rio de Janeiro.

ARNDT F.R.; RUSOH R.; STILLFRIED H.V.; HANISCH B.;MARTIN W.C.SN 49537, a new defoliant.Plant Physiology v.57,s,p.99,1976.

BAKER, B.S.; BHATIA, S.K. Factors affecting adventitious shoot regeneration from leaf explants of quince (Cydonia oblonga). Plant Cell, Tissue and Organ Culture, v.35, p.273-277, 1993.

BAKER, E.A. The influence of enviroment on-leaf wax development in Brassica oleracea var. gemmifera. New Phytology, v.73, p. 955-966, 1974.

BATT, S.; WILKINS, M.B.; VENIS, M.A. Auxin binding to corn coleoptile membranes: kinetica and specificity. Planta, v. 130, p. 7-13, 1976.

BATTEY, N.H.; LYDON, R.F. Determination and differentiation of leaf and petals primordia in Impatiens balsamina. Annals of Botany, v. 61, p. 9-16, 1988.

BRAINERD, K.E.; FUCHIGAMI, L.H. Acclimatization of asseptically cultured apple plants to low relative humidity. Journal of the American Society for Horticultural Science, v. 106, p. 515-518, 1981.

BUKATSCH, F. Bumerkungen zur doppelfarbung Astrablau-Safranin. Mikrokosmos, v.61, n.8, p. 225, 1972. 
BUTCHER,D. Bromélias brasileiras na Austrália. Revista da Sociedade Brasileira de Bromélias, v. 2, n 1,p.12-17,1995.

CAMPOSTRINI, E.; OTONI, W.C. Aclimatação de Plantas: Abordagens recentes. ABCTP-Notícias, n.25, p. 2-12, 1996.

CÂNDIDO, M.S.D. Chave artificial para o gênero Cryptanthus. Revista da Sociedade Brasileira de Bromélias, v.2, n.4, p.15-21, 1995.

CÂNDIDO,M.S.D. Cultivando Cryptanthus. Revista da Sociedade Brasileira de Bromélias, v.3, n. 1, p. 33-37, 1996.

CARAUTA, J.P.P.; SILVA, R.R. Biota em risco de extinção. Albertoa, v.4, n.6, p. 61-75, 1996.

CARVALHO, L.F.N. Palavras do Presidente. Revista da Sociedade Brasileira de Bromélias, v.1, n.4, p.1-2, 1994.

CHRISTIANSON, M.L.; WARNICK, D.A. Competence and determination in the process of $n$ vitro shoot organogenesis. Developmental Biology, v. 95, p. 288-293, 1983.

CHRISTIANSON, M.L.; WARNICK, D.A. Phenocritical times in the process of in vitro shoot organogenesis. Developmental Biology, v. 112, p. 494497, 1984.

CHRISTIANSON, M.L.; WARNICK, D.A. Temporal requirements for phytohormone balance in the control of organogenesis in vitro. Developmental Biology, v. 112, p. 494-497, 1985.

CONSOLI, L. Análise genética e molecular da variação somaclonal em Stylosanthes guianensis (Aubl.)Sw.(Leguminosae). Piracicaba,1995,108 p. Dissertação(MS)-Escola Superior de Agricultura "Luiz de Queiroz", Universidade de São Paulo.

COSTA, A. Estudo em Bromélias. Rio de Janeiro: UNIRIO, 1996. 21p.

COUTINHO, C.J.; CARVALHO, C.M. O uso da vermiculita na produção de mudas florestais. IN: Encontro Nacional de Reflorestadores, 7, Curitiba, 1983. ANAIS, p. 54-63.

COZAI, T. ; KITAYA, Y. Environmental control for large scale production of in vitro plantlets. In: TERZI, M.; CELLA, R.; FALAVIGNA, A. (Ed.) 
Current Issues in Plant Molecular and Cellular Biology, London: Kluwer Academic Publishers, 1995, p. 659-667.

DAHLEEN L.S.; STUTHMAN D.D.;RINES H.W. Agromonic trait variation in oat lines derived from tissue culture. Crop Science v.31,p. 90-94,1991.

DAVIDSON, S. E.; DONNAN, A. In vitro propagation of Cryptanthus spp. Proccedings Fla State Horticulture Society v.90, p.303. 1977.

DENG, R.; DONNELLY, D.J. In vitro hardening of red raspberry through $\mathrm{CO}_{2}$ enrichment and relative humidity reduction on sugar-free medium. Can. J. Plant Sci., v. 73, p. 1105-1113, 1993.

DESJARDINS, Y.; GOSSELIN, A.; YELLE, S. Aclimatization of "ex vitro"strawberry plantlets in $\mathrm{CO}_{2}$ - enriched enviroments and supplementary highting. Journal of the American Society for Horticultural Science, v. 112, n. 5, p. 846-851, 1987.

DIJCK, R.V., PROFT, M.; GREEF, J. Role of ethylene and cytokinins in the initiation of lateral shoot growth in bromeliads. Plant Physiology, v.86, p.836-840, 1988.

DONNELLY, D.J.; VIDAVER, W.E. Pigment content and gas exchange of red raspberry, in vitro and ex vitro. Journal of the American Society for Horticultural Science, v.109, p.177-181, 1984.

DONNELLY, D.J.; VIDAVER, W.E.; LEE, K.Y. The anatomy of tissue cultured red raspberry prior to and after transfer to soil. Plant Cell, Tissue Organ Culture, v.4, p.43-50, 1985.

FAY, M.F.; MAY, N.W.M. The in vitro propagation of Nescodom mauritianus. Botanic Gardens Micropropagation News, v.1, p.6-8, 1990.

FITCHET, M. Clonal propagation of queen and smooth cayenne pineapples. Acta Horticulturae, v.275, p.261-267, 1990a.

FITCHET, M. Organogenesis in callus cultures of pineapple (Ananas comosus (L.) Merr.). Acta Horticulturae, v.275, p.267-274, 1990 b.

FITCHET-PURNELL, M. Maximum utilisation of pineapple crows for micropropagation. Acta Horticulturae, v.334, p.325-330, 1993. 
FLINN, B.S.; WEBB, D.T.; NEWCOMB, W. The role of cell clusters and promeristemoids in determination and competence of caulogenesis by Pinnus strobus cotyledons in vitro. Canadian Journal of Botany, v. 66, p. 1556-1565, 1988.

FONTOURA, T.; COSTA A.;WENT,T. Preliminary checklist of bromeliaceae of Rio de Janeiro State,Brazil.Selbyana, v.12,p.4-45,1991.

GALLO, L.A. Atividade da Redutase do Nitrato (E.C.1.6.6.2.) sob influência de fatores físicos e químicos em feijão (Phaseolus vulgaris L.). Piracicaba, 1980. 118p. Dissertação (MS) - Universidade de São Paulo.

GONZAGA, A.L. Bromélias. Boletim Catarinense de Orquídeas e Bromélias. Ano III. n.8. p.10-11, 1997.

GRAEFF, O.R.; PAGANI, I.V. Associação fogo-capim-gordura e o desaparecimento de Alcantara imperialis. Revista da Sociedade Brasileira de Bromélias, v.3, n.1, p13-15, 1996.

GRATTAPAGLIA, D.; MACHADO, M.A. Micropropagação. In: TORRES, A.C.; CALDAS, L.S. Técnicas e aplições da cultura de tecidos e plantas - Brasília - Embrapa-CNPH, 1990. parte II. p.99-169.

GROUT, B.W.; ASTON, M.J. Transplantio of cauliflowe plants regenerated from meristem culture. I. Water loss and water transfer related to changes in leaf wac and to xylem regeneration. Horticultural reviews, v. 17, p. 1$7,1975$.

GROUT, B.W. Wax development on leaf of Brassica oleracea var. curvawong regenerated from meristem culture. Plant Science Letters, v.5, p. 401-405, 1975.

HAWBAKER, M. S.; FEHR, W. R.;MANSUR, L. M.;SHOEMAKER, R. C.; PALMER, R. G. Genetic variationfor quantitative traits in soybean lines derived from tissue culture. Theoretical and Applied Genetics,v.87, p. 49-53, 1993.

HAY, J. D.; LACERDA. L. D. Alterações nas características do solo após a fixacão de Neoregelia cruenta (R. Graham) L. B. Smith(Bromeliaceae) em um ecossistemade restinga. Ciência e Cultura, v.32, nº7, p. 863-867,1980 
HAY, J. D.; LACERDA. L. D.;TAN, A. L. Soil cation increase in a tropical sand dune ecosystem due to a terrestrial bromeliad.Ecology, v. 62, p. 392395,1981 .

HICKS, G.S. Shoot indunction and organogenesis in vitro: a developmental perspective. In vitro Cell Developmental Biology, v. 30P, p. 10-15, 1994.

HIRIMBUREGAMA, K., WIJESINGHE, L.P.J. In vitro growth of Ananas comosus L. Merr (pineapple) shoot apices on different media. Acta Horticulturae, v.319, p.203-209, 1992.

HOSOKI, T.; ASAHIRA, T. In vitro propagation of Bromeliads in liquid culture. HortScience, v.15, n.5, p.603-604, 1980.

HUETTEMAN, C.A.; PREECE, J.E. Thidiazuron: a potent cytokinin for woody plant tissue culture. Plant Cell, Tissue and Organ Culture, v.33, p.105-119, 1993.

JACOBSEN, J.V. Regulation of ribonucleic acid metabolism by plant hormones. Annual Review Plant Physiology, v.28, p. 537-564, 1977.

JONES, J. B.; MURASHIGE, T. Tissue culture propagation of Aechmea fasciata and other bromeliads.Procedings of the Internacional Plant Propagators Society, v.24, p. 117-123, 1974.

KÄMPF, A.N. Argila expandida: um substrato para bromélias em vaso. Revista da Sociedade Brasileira de Bromélias, v.2, n. 3, p.10-14, 1995.

KISS, E.; KISS, J.; GYULAI, G.; HESZLY, L. E. A novel method for rapid micropropagation of pineapple. HortScience, v.30, ${ }^{\circ} 1$, p.127-129,1995.

KUKULCZANKA, K.; CZASTKA, B. Propagation of some species of the Bromeliaceae family cultured in vitro. Acta Horticulturae, v.251, p.167$181,1989$.

LAFORGE, F.; DESJARDINS, Y.; GRAHAM, M.E.D. Miniature growth chambers for the study of environmental conditions in vitro. Can. J. Plant Sci., v.70, p.825-836, 1990.

LAKSHMANAN, P.; NG, S.K.; LOH, C.S. et al. Auxin, Cytokinin and Ethylene differentially regulate specific developmental states associated with shoot bud morphogenesis in leaf tissues of Mangosteen (Garcinia 
mangostana L.) cultured in vitro. Plant Cell Physiology, v.38, n.1, p. 5964, 1997.

LANGFORD, P. J.; WANWRIGHT,S.; Effects of sucrose concentration on the photosynthesis ability of rose shoots in vitro. Annual Botany, v.60, p. 633-640, 1987.

LEES, R.P.; EVANS, E.H.; NICHOLAS, J.R. Photosynthesis in clematis, "The President", during growth in vitro and subsquent in vivo acclimatization. Journal Experimental Botany, v. 42, p. 605-610, 1991.

LEME, E.M.C. Considerations on a new Neoregelia from Brazil. Journal Bromeliad Society, v.33, n.3, p.118-120, 1993.

LEME, E.M.C.; MARIGO, L.C. Bromeliads in the wilderness. Rio de Janeiro: Marigo Comun. Visual Ltda, 1993. 183 p.

LESHEM, B. Growth of camation meristems in vitro: anatomical structure of abnormal plantlets and the effect of agar concentration in the medium on their formation. Ann. Bot., v. 52, p. 873-876, 1983.

LUTHER, H.E. Aspectos do cultivo e da conservação de bromélias. Revista da Sociedade Brasileira de Bromélias, v. 1, n.2, p. 3-6, 1994.

MAGALHÃES, A.C.N. Fotossíntese. In: FERRI, M.G. Fisiologia Vegetal. São Paulo: EDUSP, 1979. Cap. 3, p. 117-163.

MALIK, K.A., ALI-KHAN, S.T.; SAXENA, P.K. High-frequency organogenesis from direct seed culture in Lathyrus. Annals of Botany, v.72, p.629-637, 1993.

MALIK, K.A.; SAXENA, P.K. Regeneration in Phaseolus vulgaris L.: Highfrequency induction of direct shoot formation in intact seedlings by N6benbylaminopurine and thidiazuron. Planta, v.186, p.384-389, 1992.

MARTIN, C.; PÉREZ Micropropagation of five endemic species of Limonium from the Iberian peninsula. Journal HortScience, v.70, n.1, p.97-103, 1993.

MATHEWS, V. H.; RANGAN, T.S. Multiple plantlets in lateral bud and leaf explant in vitro cultures of pineapple. Scientia Horticulturae,v. 11, p. 319-328, 1979. 
MATHEWS, V.H.; RANGAN, T.S. Growth and regeneration of plantlets in callus cultures of pineapple. Scientia Horticulturae, v.14, p.227-234, 1981 .

MATHEWS, V.H.; RANGAN, T.S.; NARAYANASWAMY, S. Micropragation of Ananas sativus in vitro Zeitschriff für Pflanzenphysiol, v.79, p. 450-454, 1976.

MEKERS, O. In vitro propagation of same Tillandsioideae (Bromeliaceae). Acta horticulture, v.78, p.311-317, 1977.

MELO, T.B. Bromélias no paisagismo. Revista da Sociedade Brasileira de Bromélias, v.3, n.1, p.3-7, 1996.

MENESCAL, R. Reprodução de Bromélias por sementes. Revista da Sociedade Brasileira de Bromélias, v.1, n. 4, p. 8-10, 1994.

MERCIER, H.; KERBAUY, G.B. In vitro multiplication of Vriesea fosteriana. Plant Cell, Tissue and Organ Culture, v.30, p. 247-249, 1992.

MERCIER, H.; KERBAUY, G.B. Micropropagation of Dyckia macedoi - an endangered endemic Brazilian bromeliad. Botanic Gardens: Micropropagation News, v.1, n.6, p.70-72, 1993.

MERCIER,H.; KERBAUY,G. B. In vitro multiplication of Vriesea hieroglyphyca, an endangered bromeliad from the Brazilian Atlantic forest. Journal of the Bromeliad Society, v. 44, p. 120-124, 1994.

MERCIER, H.; KERBAUY, G.B. The importance of tissue culture technique for conservation of endangered Brazilian bromeliads from the Atlantic rain forest canopy. Selbyana, v.16, n.2, p.147-149, 1995.

MORALES, E.A.V.; VALOIS, A.C.C.; NASS, L.L. Recursos genéticos vegetales. Brasília-EMBRAPA-CENARGEN-1997. 78p.

MURASHIGE, T.; SKOOG, F. A revised medium for rapid growth and bioassays with tobacco tissue cultures. Physiology Plantarum, v.15, p.473497, 1962. 
NAHOUM, P. I. Cultivo de Bromélias e sua intergerência nos processos evolutivos. Revista da Sociedade Brasileira de Bromélias, v.1, n.1, p.1619, 1994.

OLIVEIRA, M.G.N.; ROCHA, C.F.D.; BAGNALL, T. A comunidade animal associada à bromélia-tanque Neoregelia cruenta (R. Graham) L.B. Smith. Revista da Sociedade Brasileira de Bromélias, v.1, n.1, p.22-29, 1994.

ORLANDER, G.; DUE, K. Location of hidraulic resistence in the soil-plant pathway in seedlings of Pinus sylvestris L. grown in peat. Canadian Journal of Forest Research, v.16, n.1, p.115-128, 1986.

ORLIKOWSKA, T.K; DYER, W.E. In vitro regeneration and multiplication of safflower (Carthamus tinctorius L.). Plant Science, v.93, p.51-157, 1993.

OSBORNE, D.J. Concepts of target cells in plant differentiation. Cell Differentiation, v.14, p. 161-169, 1989.

PANNETIER, C.; LANAUD,C. Divers aspects de l'utilisationpossible des cultures in vitro pour la multiplication végétative de l'Ananas comosus $\mathrm{L}$. Merr., variété “Cayennelisse”. FRUITS, v. 31,n 12, p. 739-750,1976.

PIERIK, R. L. M.; SPRENKELS, P. A. Micropropagation of Tillandsia cyanea. Journal of the Bromeliad Society, v. 38, n², p. 9-12, 1988.

PIERIK, R.L.M. In vitro cultura of high plants as a tool in the propagation of horticultural crops. Acta Horticultural, v. 226, p.25-40, 1987.

PIERIK, R.L.M.; STEEGMANS, H.H.M. Vegetative propagation of Nidularium fulgens Lem. in vitro. Netherlands Journal Agriculture Science, v.32, p.101-106, 1984.

PIZO, M.A. O uso de bromélias por aves na Mata Atlântica da Fazenda Intervales, Sudeste do Brasil. Revista da Sociedade Brasileira de Bromélias, v.1, n.4, p.3-7, 1994.

RAMALHO, M.A.P.; SANTOS, J.B.; PINTO, C.B. Genética na agricultura. Lavras. Fundação de Apoio ao Ensino, Pesquisa e Extensão, 1990. 359 p.

ROCHA, C.F.D.; SLUYS,V.M.; ORNELLAS, A.B. et al. O efeito do fogo em populações naturais de Vriesea neoglutinosa em uma restinga relicta no 
Espírito Santo. Revista da Sociedade Brasileira de Bromélias, v.3, n.1, p.16-26, 1996.

SÁ, V. Estudo define áreas que devem ser conservadas. Folha de São Paulo, São Paulo, 7 abril. 1996. p.16.

SAMYN, G.; THOMAS, F. Os belgas e as bromélias: Parte I. O século XIX: Bélgica uma nação horticultural. Revista da Sociedade Brasileira de Bromélias, v.1, n¹, p. 3-8, 1995.

SHARMA, N.; CHANDEL, K.P.S. Low-temperature storage of Rauvolfia serpentina Benth. ex Kurz.: an endangered, endemic medicinal plant. Plant Cell Reports, v.11, p. 200-232, 1992.

SOUZA, R.C.O.S.; NEVES, L.J. Anatomia foliar de quatro espécies de Tillandisia. Revista da Sociedade Brasileira de Bromelias, v.3, n.5, p.28-39,1996.

SPURR, S.H.; BARNES, B.Y. Forest Ecology. New York, The Ronald Press, 1973, $571 \mathrm{p}$.

SUTTER, E.; LANGHANS, R.W. Epicuticular wax formation on carnation plantlets regenerated from shoot tip culture. Journal American Society HortScience, v. 104, p. 493-496, 1979.

TOMBOLATO, A.F.C.; TABEBAYASHI, S.S.G., COSTA, A.M.M.; QUIRINO, E.A. Cultura in vitro da Bromélia. O Agronômico, v.43, n.2/3, p.77-78, 1991.

TREWAVAS, A. What is the molecular basis of plant hormone action? Trends Biochemistry Science, v.4, p. 199-202, 1979.

TURK, B.A.; SWARTZ, H.J; ZIMMERMAN, R.H. Adventitious shoot regeneration from in vitro-cultured leaves of Rubus genotypes. Plant Cell, Tissue and Organ Culture, v.38, p.11-17, 1994.

VAN ARNOLD, S.; HAWES, C. Differentiation of bud mersitems and cataphylls during adventitious bud formation on embryos of Picea abies. Canadian Journal of Botany, v.67, p. 422-428, 1989.

VAN COTTHEM, W.R.J. A classification of stomatal types. Boletim Sociedade Argentina Botânica, V. 15, n.1, p. 126-129, 1974. 
VAN SLUYS, M.; STOTZ, F.D. Padrões de visitação à Vriesea neoglutinosa por beija-flores no Espírito Santo, Sudeste do Brasil. Revista da Sociedade Brasileira de Bromélias, v.2, n.3, p. 27-35, 1995.

VINTERHALTER, B.; VINTERHALTER, D. True-to-the type in vitro propagation of Aechmea fasciata Baker. Scientia Horticulturae, v.57, p.253-263, 1994.

WETZSTEIN, H.Y.; SOMMER, H.E. Leaf anatomy of tissue-cultured Liquidambar styraciflua (Hammamelidaceae) during acclimatization. Am. J. Bot., v. 69, n.10, p. 1579-1586, 1982.

YANG, Q.G.; READ, P.E.; FELLMAN, C.D. et al. Effect of cytckinin, IBA and rootting regime on chinese chestnut cultured in vitro. HortScience, v.21, p.133-134, 1990.

ZEPEDA, C.; SAGAWA, Y. In vitro Propagation of Pineapple. HortScience, v.31, n.1, p.127-129, 1982.

ZIMMER, K.; PIEPER, W. Methods and problems of clonal propagation of bromeliads in vitro. Acta horticulturae,v. 64, p.25-29, 1976.

ZIMMERMAN, R.H. Micropropagation of woody plants: post tissue culture aspects. Acta Horticulture, v. 227, p.489-99, 1988.

ZORNIG, R.K. Micropropagção de bromélias. Revista da Sociedade Brasileira de Bromélias, v.3, n.3, p.3-8, 1996. 